\title{
The ratio of methanogens to methanotrophs and water-level dynamics drive methane transfer velocity in a temperate kettle-hole peat bog
}

\author{
Camilo Rey-Sanchez ${ }^{1, a}$, Gil Bohrer ${ }^{1}$, Julie Slater ${ }^{2}$, Yueh-Fen Li ${ }^{3}$, Roger Grau-Andrés ${ }^{2}$, Yushan Hao ${ }^{2}$, \\ Virginia I. Rich ${ }^{3}$, and G. Matt Davies ${ }^{2}$ \\ ${ }^{1}$ Department of Civil, Environmental and Geodetic Engineering, \\ The Ohio State University, Columbus, Ohio 43210, USA \\ ${ }^{2}$ School of Environment and Natural Resources, The Ohio State University, Columbus, Ohio 43210, USA \\ ${ }^{3}$ Department of Microbiology, The Ohio State University, Columbus, Ohio 43210, USA \\ ${ }^{\mathrm{a}}$ current address: Department of Environmental Science, Policy, and Management, \\ University of California, Berkeley, California 94720, USA
}

Correspondence: Camilo Rey-Sanchez (rey.1@ berkeley.edu)

Received: 28 March 2019 - Discussion started: 23 April 2019

Revised: 20 July 2019 - Accepted: 31 July 2019 - Published: 29 August 2019

\begin{abstract}
Peatlands are a large source of methane $\left(\mathrm{CH}_{4}\right)$ to the atmosphere, yet the uncertainty around the estimates of $\mathrm{CH}_{4}$ flux from peatlands is large. To better understand the spatial heterogeneity in temperate peatland $\mathrm{CH}_{4}$ emissions and their response to physical and biological drivers, we studied $\mathrm{CH}_{4}$ dynamics throughout the growing seasons of 2017 and 2018 in Flatiron Lake Bog, a kettle-hole peat bog in Ohio. The site is composed of six different hydrobiological zones: an open water zone, four concentric vegetation zones surrounding the open water, and a restored zone connected to the main bog by a narrow channel. At each of these locations, we monitored water level (WL), $\mathrm{CH}_{4}$ pore-water concentration at different peat depths, $\mathrm{CH}_{4}$ fluxes from the ground and from representative plant species using chambers, and microbial community composition with a focus here on known methanogens and methanotrophs. Integrated $\mathrm{CH}_{4}$ emissions for the growing season were estimated as $315.4 \pm 166 \mathrm{mgCH}_{4} \mathrm{~m}^{-2} \mathrm{~d}^{-1}$ in 2017 and $362.3 \pm$ $687 \mathrm{mg} \mathrm{CH}_{4} \mathrm{~m}^{-2} \mathrm{~d}^{-1}$ in 2018. Median $\mathrm{CH}_{4}$ emission was highest in the open water, then it decreased and became more variable through the concentric vegetation zones as the WL dropped, with extreme emission hotspots observed in the tamarack mixed woodlands (Tamarack) and low emissions in the restored zone (18.8-30.3 $\left.\mathrm{mg} \mathrm{CH}_{4} \mathrm{~m}^{-2} \mathrm{~d}^{-1}\right)$. Generally, $\mathrm{CH}_{4}$ flux from above-ground vegetation was negligible compared to ground flux $(<0.4 \%)$, although blueberry plants
\end{abstract}

were a small $\mathrm{CH}_{4}$ sink. Pore-water $\mathrm{CH}_{4}$ concentrations varied significantly among zones, with the highest values in the Tamarack zone, close to saturation, and the lowest values in the restored zone. While the $\mathrm{CH}_{4}$ fluxes and pore-water concentrations were not correlated with methanogen relative abundance, the ratio of methanogens to methanotrophs in the upper portion of the peat was significantly correlated to $\mathrm{CH}_{4}$ transfer velocity (the $\mathrm{CH}_{4}$ flux divided by the difference in $\mathrm{CH}_{4}$ pore-water concentration between the top of the peat profile and the concentration in equilibrium with the atmosphere). Since ebullition and plant-mediated transport were not important sources of $\mathrm{CH}_{4}$ and the peat structure and porosity were similar across the different zones in the bog, we conclude that the differences in $\mathrm{CH}_{4}$ transfer velocities, and thus the flux, are driven by the ratio of methanogen to methanotroph relative abundance close to the surface. This study illustrates the importance of the interactions between water-level and microbial composition to better understand $\mathrm{CH}_{4}$ fluxes from bogs and wetlands in general. 


\section{Introduction}

Methane $\left(\mathrm{CH}_{4}\right)$ fluxes from natural and anthropogenic sources play a significant role in determining atmospheric climate forcing (Ciais et al., 2013). Changes to $\mathrm{CH}_{4}$ fluxes from natural systems are of significant concern due to their potential to drive positive feedback cycles in the global climate system (Bridgham et al., 2013; Dean et al., 2018). Natural wetlands emit approximately $30 \%$ of all the methane $\left(\mathrm{CH}_{4}\right)$ released into the atmosphere (Kirschke et al., 2013), yet the uncertainty around wetland $\mathrm{CH}_{4}$ flux is the highest of all the components of the global $\mathrm{CH}_{4}$ budget (Kirschke et al., 2013). This uncertainty partly arises from the complexity of physical and biological interactions that result in the production and oxidation of $\mathrm{CH}_{4}$ and its eventual release to the atmosphere (Lai, 2009). Generally, water level (WL) is the most important driver of $\mathrm{CH}_{4}$ emissions from wetlands, and especially peatlands, as its position in the soil or peat profile defines the boundary between anaerobic $\mathrm{CH}_{4}$ production (methanogenesis) in the catotelm (i.e. the lower anoxic portion of the peat) and aerobic $\mathrm{CH}_{4}$ oxidation (methanotrophy) in the acrotelm (the upper oxic peat; Kettunen, 2003; White et al., 2008). However, a plethora of environmental variables can also influence $\mathrm{CH}_{4}$ fluxes in peatlands, including temperature (Bohn et al., 2007; Kim et al., 1999; Segers, 1998); peat origin (e.g. Sphagnum, woody peat, and fen and reed peat; Bridgham and Richardson, 1992); degree of humification (Glatzel et al., 2004); availability of labile carbon in the peat (Updegraff et al., 1995); concentrations of lignin, long-chain fatty acids, and polysaccharides along the peat profile (Hoyos-Santillan et al., 2016); phosphorous content, which regulates anaerobic decomposition of organic matter (Basiliko et al., 2007); the abundance of other electron acceptors, especially Fe (Chamberlain et al., 2018); and pH, as methanogens occur at greater abundances in neutral to slightly alkaline conditions (Wang et al., 1993). It is also important to be cognisant of reports of $\mathrm{CH}_{4}$ production in aerobic soil (Angle et al., 2017) and an increased awareness of the importance of anaerobic oxidation of $\mathrm{CH}_{4}$ (Smemo and Yavitt, 2011).

The microbiota of a site can have complex interactions with WL and other physical conditions, which result in variable $\mathrm{CH}_{4}$ fluxes. Despite the increasingly complex picture emerging of peatland $\mathrm{CH}_{4}$ cycling, it has been estimated that methanotrophy can oxidize $60 \%-90 \%$ of the $\mathrm{CH}_{4}$ produced in wetlands before it can escape to the atmosphere (Le Mer and Roger, 2001). Research has also shown that water table drawdowns reduce the abundance of methanogens (Kim et al., 2008) and that changes in ecosystem vegetation and structure can affect microbial community composition and, in turn, the $\mathrm{CH}_{4}$ biochemistry of wetlands (McCalley et al., 2014). Generally, peat bogs are nutrient-poor sites dominated by hydrogenotrophic methanogenesis, but when disturbance occurs, a change from hydrogenotrophic to acetoclastic methanogenesis can occur due to an increase in $\mathrm{pH}$ and nutrients (Kelly et al., 1992; Kim et al., 2008; Kotsyurbenko et al., 2004).

Kettle-hole peat bogs are peatlands created by the accumulation of peat in areas previously occupied by kettle lakes. Kettle-hole peat bogs, which are frequently found in eastern North America (Cai and Yu, 2011; Moore, 2002), often consist of water bodies surrounded by different vegetation zones. Closest to the open water there is often a mat of floating vegetation followed by concentrically organized vegetation zones that ultimately support shrubs and trees (Vitt and Slack, 1975). This vegetation heterogeneity can be an important driver of $\mathrm{CH}_{4}$ fluxes (Lai et al., 2014), particularly in ombrotrophic peat bogs where vegetation communities and water levels are strongly associated (Malhotra et al., 2016). Measurements of $\mathrm{CH}_{4}$ flux in different vegetation zones are important in understanding site-level flux estimates at the bog scale that are affected by the relative cover and arrangement of different vegetation zones (Nadeau et al., 2013). Most importantly, a better understanding of the biological, chemical, and physical processes controlling fluxes at these low resolutions is necessary to scale up $\mathrm{CH}_{4}$ fluxes at the ecosystem level (Bridgham et al., 2013). The objectives of this study were to (1) calculate the growing-season $\mathrm{CH}_{4}$ budget of a kettle-hole peat bog in Ohio by upscaling flux measurements from different vegetation zones, (2) quantify the effects of biotic and abiotic controls on below-ground vertical profiles of $\mathrm{CH}_{4}$ pore-water concentration and related fluxes, and (3) determine the links between microbial community structure and associated $\mathrm{CH}_{4}$ dynamics. Brief comparisons of $\mathrm{CH}_{4}$ dynamics between restored and undisturbed section are discussed but not in detail, as the evaluation of the effect of restoration on $\mathrm{CH}_{4}$ fluxes is not the objective of this paper.

\section{Methods}

\subsection{Study site}

We studied Flatiron Lake Bog, a ca. 14.4 ha kettle-hole peat bog located in northeastern Ohio $\left(41^{\circ} 02^{\prime} 40.67^{\prime \prime} \mathrm{N}\right.$, $81^{\circ} 21^{\prime} 59.81^{\prime \prime} \mathrm{W}$; Fig. 1). The site is a state nature preserve and has been owned by The Nature Conservancy (TNC) since 1984. The greater part of the site typifies the characteristic abiotic and biotic zonation found in similar sites throughout eastern North America. A small area (ca. $1120 \mathrm{~m}^{2}$ ) of open water (Water) is located at the center of the site and is surrounded by a series of concentrically organized vegetation zones. The vegetation community of the site, including the bog vegetation and upland zones, was described in detail by Colwell (2009). The closest zone to the open water, hereafter called the Sphagnumleatherleaf mat (Mat), consists of a floating mat of Sphagnum fallax (H. Klinggr.), with abundant cover of swamp loosestrife (Decodon verticillatus (L.) Elliot) and leather- 


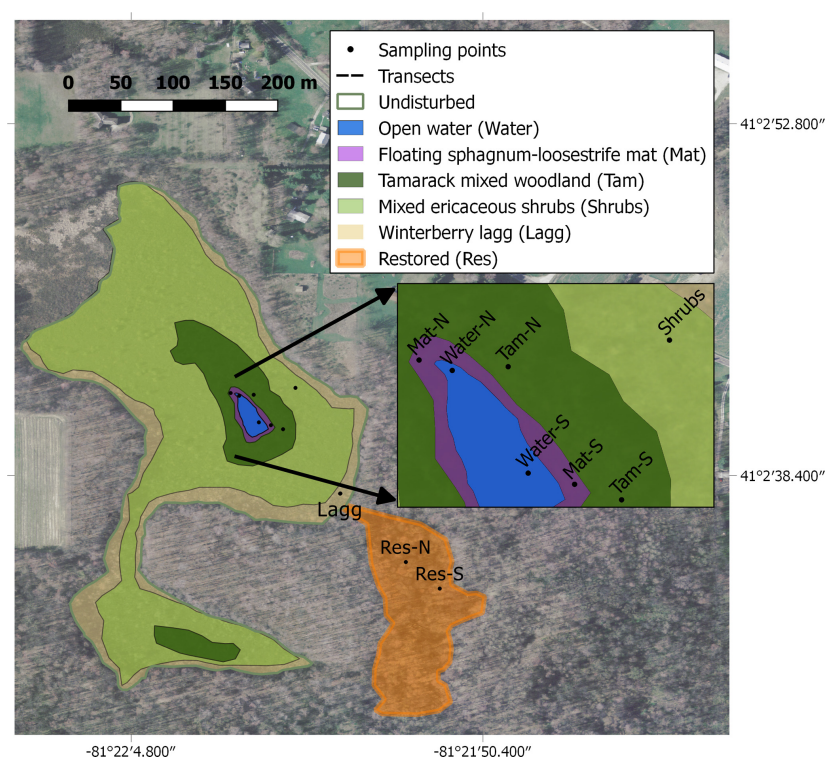

Figure 1. Map of the study site showing the different hydrobiological zones and the sampling locations. The map was created with QGIS, and the image was downloaded from the Ohio Geographically Referenced Information Program (OGRIP) (http: //gis5.oit.ohio.gov/geodatadownload/, last access: 2 February 2018, image reference number: N2280505 and N2280500).

leaf (Chamaedaphne calyculata (L.) Moench). Further away from the open water, and surrounding the Mat, is a narrow band of tamarack mixed woodland (Tamarack). The Tamarack zone is characterized by tamarack (Larix laricina $(\mathrm{Du}$ Roi) K. Koch) and yellow birch (Betula alleghaniensis Britton), with a ground layer dominated by $S$. fallax. Further towards the bog's periphery, one can find a large area of mixed ericaceous shrubs (Shrubs) dominated by highbush blueberry (Vaccinium corymbosum L.) and huckleberry (Gaylussacia baccata (Wangenh.) K. Koch), with a ground layer of Sphagnum and scattered sedges, ferns, and forbs. The Shrubs zone also includes occasional patches dominated by winterberry (Ilex glabra (L.) A. Gray) or mature hardwoods, such as red maple (Acer rubrum L.) and yellow birch. Finally, the outermost area consists of a lagg or moat, hereafter called the winterberry lagg (Lagg). The Lagg is typically inundated during the first half of the growing season but dry during extended periods of the year. The dominant vegetation on the Lagg includes winterberry (I. glabra) and buttonbush (Cephalanthus occidentalis L.). The Water, Mat, and Tamarack zones generally present water levels that are always at (Water and Mat), or near (Tamarack) the surface, and together they are hereafter referred to as the permanently wetted area. In contrast, the Shrubs and Lagg zones have deeper water tables with more pronounced fluctuations in water level and are hereafter referred to as the intermittently wetted area. Peat coring and manual depth probing revealed a gradient in peat depths from the margin of the site to the interior. Measured peat depths varied from $>0.3 \mathrm{~m}$ in the Lagg areas to $>10 \mathrm{~m}$ close the center of the site. The immediate upland area surrounding the bog is mostly forested, with dominant tree species including the American beech (Fagus grandifolia L.), black oak (Quercus velutina Lam.), and red maple (Acer rubrum L.). The width of this forested buffer varies, and some parts of the site are in proximity to areas under arable production, roads, or buildings (Fig. 1).

In addition to this relatively unaltered core area of the site, there is a restored section (Res) in the southern part of the bog, which is connected to the main area by a narrow channel (Fig. 1) and comprises $19 \%$ of the total peatland (ca. $23430 \mathrm{~m}^{2}$ ). During the $1950 \mathrm{~s}$, this area was disturbed and drained to provide water for gravel- and sand-mining activities in adjacent areas. Peat coring in this area has revealed evidence of fire disturbance with significant deposits of charcoal and char layers. Between 2001 and 2003 TNC implemented a few restoration interventions in this area. This included opening of the channel to reconnect the two sections of the bog and the installation of a water-control structure to raise the water table at the restored section. Elevated water tables suppressed red maple trees that had colonized the site since the disturbance and enabled the establishment of bog vegetation. The latter process was aided by the transfer of Sphagnum diaspores and the planting of Vaccinium spp. The current vegetation community for the restored section is dominated by winterberry (I. glabra), buttonbush (C. occidentalis), invasive glossy buckthorn (Frangula alnus Mill.), and a remnant population of red maple trees. Thin discontinuous mats of Sphagnum spp. and Carex spp. dominated the ground layer. Due to its limited connection to the core of the site, and its history of modification, degradation, and restoration, we consider the Res zone to be a distinct hydrobiological zone, and due to its large variation in water level, we consider this zone to be part of the intermittently wetted area as well.

\subsection{Experimental design}

Across the site, we established multiple sampling locations to assess ecosystem carbon fluxes, $\mathrm{CH}_{4}$ pore-water concentrations, peat properties, water table dynamics, and microbial community composition. Monitoring included locations within both the undisturbed and restored sections of the bog. In the permanently wetted area we initiated two transects with their start points located to the north and south of the open water in the center of the bog (Fig. 1). Each transect included three sampling locations, each associated with a vegetation zone: Water, Mat, and Tamarack. In the intermittently wetted area, sampling locations for Shrubs and Lagg were selected as shown in Fig. 1. Most locations were established in summer 2017, but the Tamarack location on the north transect and the Lagg location were added in the spring of 2018. For the restored section two randomly selected locations were sampled, a northern location towards the center of 
the restored section (Res-N) and a southern location near the edge (Res-S). Fewer sampling locations in the restored section were justified by the more homogenous vegetation composition at the section scale and the section's smaller area.

\subsection{Surface $\mathrm{CH}_{4}$ flux chamber measurements}

In $2017, \mathrm{CH}_{4}$ gas transfer at the peat surface was measured monthly between June and October using non-steady-state chambers. We sampled two to four chambers monthly in each sampling location at each zone. Chambers were deployed on top of semi-permanent collars that were installed 3 months prior to the first round of sampling. The collars in the Water, Tamarack, Shrubs, and Res zones were made of rectangular high-density polyethylene (HDPE) boxes, with dimensions of $38 \mathrm{~cm} \times 56 \mathrm{~cm}$ and a height of $26 \mathrm{~cm}$. During sampling, the collars and the chambers had a foam seal and were held together with clamps. For the open-water chambers, closed-cell polyethylene pipe insulation $(1.3 \mathrm{~cm}$ internal diameter) was attached to the bottom edge of the chamber to facilitate flotation and create a seal with the water surface (Rey-Sanchez et al., 2018). For the Mat zone, we used tall chambers with a volume of $121 \mathrm{~L}$ (height $82 \mathrm{~cm}$ and radius $28 \mathrm{~cm}$ ), with circular collars with a $28 \mathrm{~cm}$ radius and a height of $59 \mathrm{~cm}$ that were inserted ca. $30 \mathrm{~cm}$ into the mat for a total chamber height of ca. $121 \mathrm{~cm}$. The height of the chambers was necessary to fit the tall and abundant loosestrife and leatherleaf plants. Due to their larger volume, these chambers included fans at 30 and $85 \mathrm{~cm}$ above the surface to improve air mixing within the chamber during sampling. The volume of the plants within the chamber was considered negligible.

All chambers included a thermometer to measure air temperature, a $3 \mathrm{~m}$ long Tygon tube (1.6 $\mathrm{mm}$ internal diameter) used as a vent for stabilizing pressure, and a $20 \mathrm{~mm}$ gray butyl stopper that served as a sampling port. In 2017 gas samples were extracted from the chambers using a syringe $(30 \mathrm{~mL})$. Here $20 \mathrm{~mL}$ of the gas sample was introduced into evacuated $10 \mathrm{~mL}$ vials to keep it over-pressurized. We used a closure time of $30 \mathrm{~min}$ for each chamber and extracted a sample every $5 \mathrm{~min}$ for a total of seven samples per chamber. The gas extracted from the chamber was transported to the laboratory to be analyzed on a gas chromatograph (Shimadzu GC-2014, Shimadzu Scientific Instruments, Kyoto, Japan). Fluxes were calculated from the slope of the linear regression of the molar density of the greenhouse gas vs. time. We incorporated selection criteria for rejecting outliers from individual chamber measurements as described in Morin et al. (2017). Specifically, if the $r^{2}$ value of the linear regression of molar density vs. time was not sufficiently high $\left(r^{2} \geq 0.85\right)$, and the $p$ value was higher than 0.05 , we removed one outlier point (identified as the point with the highest residual value) from the regression. This was done up to twice per chamber, and if the accumulation rate regression still did not meet the selection requirements, the entire chamber observation was rejected. This approach leads to the exclusion of cases where ebullition events occur during the sampling, creating a non-linear change in concentration. The procedure for calibration of the gas chromatograph is based on previous studies at the same facility (Nahlik and Mitsch, 2010; Sha et al., 2011) and was fully described in Morin et al. (2017).

In 2018, surface fluxes were measured monthly and at the same locations as in 2017 and the additional Lagg and Tamarack locations. We used a portable infrared gas analyzer (Picarro GasScouter G4301, Picarro Inc., Santa Clara, CA) adapted to sample the same chambers as used in 2017. Given the higher sampling rate of the Picarro (one point per second) the fluxes were calculated based on a linear regression of the molar density of $\mathrm{CH}_{4}$ over 2-4 min depending on the volume of the chamber and the strength of the response of gas concentration vs. time. Due to the higher number of points (146-293 per regression), a stricter $p$ value was implemented $(p<0.001)$ to determine the significance of the regression. A lack of a significant correlation within a chamber measurement set was assumed to equal a zero flux.

Diurnal patterns of $\mathrm{CH}_{4}$ emissions for the four main zones in the bog (Open, Mat, Tamarack, and Shrubs) were measured in September in O-S, Mat-S, Tamarack-S, and Shrubs locations (Fig. 1). Four individual chamber measurements per location were completed throughout a full $24 \mathrm{~h}$ cycle with a frequency of approximately $3 \mathrm{~h}$. Chamber measurements were accompanied by measurements of surface or water temperature when appropriate.

\section{$2.4 \mathrm{CH}_{4}$ flux from plants}

To estimate potential emission of $\mathrm{CH}_{4}$ through the plant tissues of larger sub-canopy and canopy trees and shrubs, which would be missed by chambers, we measured plant fluxes in dominant vascular species near the location of the surface measurements. Fluxes from plants were sampled monthly in June, July, and September 2018 using the Picarro gas scouter with chambers adapted to fit individual leaves or branch sections. Measurements were taken at multiple times during the day in June, July, and September, while a full diurnal pattern was performed in September.

To measure fluxes coming directly through the plant tissue in the Mat zone, we used small chambers on loosestrife stems, the most abundant plant species in this zone. These chambers had a small opening in the corner of one of the sections to allow the stem to sit uncompressed. The spaces around the stem hole were sealed with putty. This loosestrifestem chamber enclosure had dimensions of $34 \mathrm{~cm} \times 21 \mathrm{~cm} \times$ $12.4 \mathrm{~cm}$ and a volume of $11.4 \mathrm{~L}$.

We used fully mature and healthy-looking loosestrife stems with more than $200 \mathrm{~cm}^{2}$ of area for plant-flux calculations. Stems were measured five times throughout the day in June and twice in July and September, adding up to nine observations throughout the season. After 2-3 min of measurements, the stem was cut, wrapped in a moist paper towel, and 
put in a cooler for calculation of leaf area. The leaves were detached from the stem and petioles, arranged on a sheet of paper, and put on a scanner with a reference scale. The images were analyzed with the software ImageJ (Schneider et al., 2012) for calculation of total leaf area.

Plant-flux measurements at the Tamarack zone were conducted on stems and trunk sections of Tamarack, while fluxes at the Shrubs were measured from blueberry stems. To measure fluxes coming from trunk sections we used an adaptation of the chambers used by Pangala et al. (2013) for tropical wetlands. These chambers had two sections that were sealed with insulation foam that closed around the trunk and that were held together tightly with clips. When holes around the trunk were present, additional layers of insulation foam were added to guarantee a good seal. The volume of the trunk inside the chamber was measured to subtract from the total volume of the chamber, which was $106 \mathrm{~L}$. The dimensions of all the enclosures were $76 \mathrm{~cm} \times 112 \mathrm{~cm} \times 52 \mathrm{~cm}$. The understory fluxes from the low stems of the Tamarack as well as blueberry, the most abundant plant in the understory in the Tamarack and Shrubs zones, were measured using stem chambers. Trunk fluxes were measured six times in the months of May and July. For stem flux calculation, we used fully mature and healthy tamarack stems growing at a reachable height. Stems were measured twice in May, seven times in June, five times in July, and twice in September. Blueberry twigs were sampled at multiple locations within the Shrubs zones, four times in June, four times in July, and twice in September.

\subsection{Upscaling of $\mathrm{CH}_{4}$ fluxes}

To scale up the fluxes from each of the zones we extrapolated monthly mean chamber measurements to the entire area of each zone. We then integrated the monthly observed flux to calculate the total seasonal $\mathrm{CH}_{4}$ budget for each zone and added the contribution of all the zones for the total seasonal site total. When fluxes from plants were significant, we calculated the total contributions by first multiplying the per-leaf-area rate observed by the plant chamber measurement by the leaf-area index, then multiplying by the area of the zone, and finally integrating in time for the whole season. The leaf-area index (LAI) was calculated based on the MODIS LAI product (image collection ID: MODIS/006/MCD15A3H, available through the Google Earth Engine) for the period of study. Due to the low resolution of the imagery with respect to the site $(500 \mathrm{~m})$, we calculated the average LAI of the two images intersecting the site, which comprised similar areas.

Due to the lack of strength in the signal of the diurnal pattern, we did not correct the monthly measurements by time of day. The measurements in 2017 encompassed a total of $122 \mathrm{~d}$ for which the integration of fluxes was performed. The length of this period was higher in 2018 and was equal to $149 \mathrm{~d}$.

\subsection{Vertical profiles of $\mathrm{CH}_{4}$ pore-water concentration and methane transfer velocity}

We used in situ, dialysis, pore-water samplers ("peepers"; Angle et al., 2017; MacDonald et al., 2013) to measure vertical pore-water concentration profiles of dissolved $\mathrm{CH}_{4}$. In total, seven peepers were installed throughout the site: five in the undisturbed section and two in the restored section. Peepers were placed adjacent to the gas flux chambers. Each peeper had 10 sampling windows located at depths from 1.4 to $51.8 \mathrm{~cm}$ and spaced every $5.6 \mathrm{~cm}$. Each window $(8.89 \mathrm{~cm} \times 2.28 \mathrm{~cm}$ area and $3.02 \mathrm{~cm}$ depth $)$, which was filled with deionized water that equilibrates with the surrounding pore water through a semi-permeable membrane (pore size $0.2 \mu \mathrm{m}$; Sterlitech Corporation, Kent, WA), was connected to two UV-resistant Tygon tubes that extended to the surface. When one tube water was suctioned using a syringe, the other was connected to a nitrogen bag to replace the volume of water extracted. Extracted samples were stored in $10 \mathrm{~mL}$ glass vials, each containing $100 \mu \mathrm{L}$ of hydrochloric acid ( $2 \mathrm{M})$ to prevent any biological reactions. Samples were kept in a cooler at low temperatures (ca. $4^{\circ} \mathrm{C}$ ) for no longer than $2 \mathrm{~d}$ before processing.

Samples were processed with the goal of measuring the concentration of dissolved gases in the water; $5 \mathrm{~mL}$ of the water sample was extracted from each vial and placed in a syringe pre-filled with $20 \mathrm{~mL}$ of $\mathrm{N}_{2}$ gas. The syringes were shaken vigorously for $15 \mathrm{~min}$, and $20 \mathrm{~mL}$ of the headspace was extracted into a new $10 \mathrm{~mL}$ glass vial. The pore-water concentrations of the samples were calculated based on the headspace concentration of the gas in equilibrium with the liquid sample according to Henry's law of equilibrium of gases in a liquid-air interface. The coefficient of equilibrium for $\mathrm{CH}_{4}$ was $67.13 \mathrm{~L} \mathrm{MPa} \mathrm{mol}^{-1}$. The gas samples were analyzed in a gas chromatograph with a flame ionization detector (FID; Shimadzu GC-2014, Shimadzu Scientific Instruments, Kyoto, Japan).

By combining pore-water concentration at the surface with the associated fluxes, estimations of methane transfer velocity were obtained as in previous studies in forested ponds and lakes (Holgerson et al., 2017; Schilder et al., 2016; Wanninkhof, 2014). Through this approach, the flux at the waterair interface can be calculated using the bulk formulation:

$F_{\mathrm{CH}_{4}}=k\left(C_{\mathrm{w}}-C_{\mathrm{eq}}\right)$,

where $F_{\mathrm{CH}_{4}}$ is the diffusive $\mathrm{CH}_{4}$ flux $\left(\mathrm{molm}^{-2} \mathrm{~s}^{-1}\right), k$ is the $\mathrm{CH}_{4}$ transfer velocity $\left(\mathrm{m} \mathrm{s}^{-1}\right), C_{\mathrm{w}}$ is the concentration of methane in the pore water at the surface $\left(\mathrm{mol} \mathrm{m}^{-3}\right)$, and $C_{\text {eq }}$ is the concentration of $\mathrm{CH}_{4}$ in equilibrium with the atmosphere $\left(\mathrm{mol} \mathrm{m}^{-3}\right) . C_{\text {eq }}$ is calculated by multiplying the mixing ratio of $\mathrm{CH}_{4}$ in the atmosphere $\left(r\right.$; in $\left.\mathrm{mol} \mathrm{mol}^{-1}\right)$ by the atmospheric pressure ( $P$; in MPa) and dividing by Henry's law coefficient of equilibrium for $\mathrm{CH}_{4}\left(K_{\mathrm{H}}\right)$ of 
$0.067 \mathrm{~m}^{3} \mathrm{MPa} \mathrm{mol}^{-1}$ as in Eq. (2):

$C_{\text {eq }}=\frac{r P}{K_{\mathrm{H}}}$.

$C_{\text {eq }}$ was calculated first with a constant $r\left(2 \mu \mathrm{mol} \mathrm{mol}^{-1}\right)$ and second with the value of the average of the initial $r$ of the chamber measurements associated with each flux calculation. These two methods produced nearly identical results in $C_{\text {eq }}$ when compared to the much higher values of $C_{\mathrm{w}}$. The constant mixing ratio was chosen for the rest of the analyses given the uncertainty associated with the initial concentration from the chambers. In the case of our peat bog, $C_{\mathrm{w}}$ can be calculated by multiplying pore-water concentration $\left(\left[\mathrm{CH}_{4}\right]\right)$ by peat porosity ( $\Phi$; see ancillary measurements below):

$C_{\mathrm{w}}=\left[\mathrm{CH}_{4}\right] \Phi$,

where $\left[\mathrm{CH}_{4}\right]$ was calculated in the top stratigraphic layer of the peat $(\mathrm{ca} .10 \mathrm{~cm})$. Finally, methane transfer velocity can be calculated as

$k=\frac{F_{\mathrm{CH}_{4}}}{C_{\mathrm{w}}-C_{\mathrm{eq}}}$.

We focus on the top $10 \mathrm{~cm}$ because, first, this is the section where the atmospheric exchange occurs. Secondly, this section should be the most active one for both methanogens and methanotrophs (Angle et al., 2017), since it includes the more aerobic acrotelm as well as less well-humified peat (greater labile $\mathrm{C}$ availability).

\subsection{Core sampling, DNA extraction, and 16S rRNA amplicon sequencing and analysis}

We analyzed the microbial composition of peat cores adjacent to the peepers. Three cores were extracted in August 2017 from within $5 \mathrm{~m}$ of the peepers located in the Mat-S, Tamarack-S, Shrubs, Res-N, and Res-S zones. The cores were extracted using a rectangular Wardenaar peat corer with an aperture area of $12 \mathrm{~cm} \times 12 \mathrm{~cm}$ and $>50 \mathrm{~cm}$ length. Core horizons were sampled in the field according to obvious stratigraphy (by color, texture, and von Post humification). Representative ca. $10 \mathrm{~cm}$ long samples of each horizon were stored at $4{ }^{\circ} \mathrm{C}$ and processed the next day for microbial analyses. Processing involved dividing each section vertically into three sub-samples, which were homogenized before a $0.25 \mathrm{~g}$ sub-sample was extracted from each. A fourth $0.25 \mathrm{~g}$ sub-sample was taken following homogenization of all the remaining material from a given section. All sub-samples were stored at $-20^{\circ} \mathrm{C}$ for no more than 3 months until DNA extraction. DNA was extracted using DNeasy PowerSoil Kit (Qiagen, Hilden, Germany) following the manufacturer's protocol. Extracted DNA was quantified with NanoDrop 8000 (Thermo Fisher Scientific, Waltham, WA). The 16S rRNA V4 region was then amplified and sequenced on the Illumina MiSeq platform (Illumina, San
Diego, CA), at Argonne National Labs, via the Earth Microbiome Project (http://www.earthmicrobiome.org/, last access: 3 January 2019) post-2015 barcoded primer set. These primers (515F; Parada et al., 2016; CGTGYCAGCMGCCGCGGTAA - 806R, April, GGACTACNVGGGTWTCTAAT, forward-barcoded; Parada et al., 2016, and Apprill et al., 2015) are adapted for Illumina HiSeq2000 and MiSeq by the addition to the forward primer of a $5 \mathrm{ft}$ Illumina adapter to support paired-end sequencing, a 12-base barcode sequence to support sample pooling in each lane and forward pad and linker sequences, and the addition to the reverse primer of a $3 \mathrm{ft}$ Illumina adapter and reverse pad and linker sequences (Caporaso et al., 2010, redesigned by Walters et al., 2016). Each $25 \mu \mathrm{L}$ polymerase chain reaction (PCR) contained $12 \mu \mathrm{L}$ of MO BIO PCR water (certified DNA-free), $10 \mu \mathrm{L}$ of 5PRIME HotMasterMix $(1 \times), 1 \mu \mathrm{L}$ of forward primer $(5 \mu \mathrm{M}$ concentration, $200 \mathrm{pM}$ final), $1 \mu \mathrm{L}$ Golay barcode-tagged reverse primer $(5 \mu \mathrm{M}$ concentration, $200 \mathrm{pM}$ final), and $1 \mu \mathrm{L}$ of template DNA. The conditions for PCR were as follows: $94^{\circ} \mathrm{C}$ for 3 min to denature the DNA, with 35 cycles at $94^{\circ} \mathrm{C}$ for $45 \mathrm{~s}, 50^{\circ} \mathrm{C}$ for $60 \mathrm{~s}$, and $72^{\circ} \mathrm{C}$ for $90 \mathrm{~s}$, with a final extension at $72^{\circ} \mathrm{C}$ for $10 \mathrm{~min}$ to ensure complete amplification. The PCR amplicons were quantified using PicoGreen (Invitrogen, Carlsbad, CA) and a plate reader. Once quantified, various volumes of each of the amplicons were pooled into a single tube for equal representation of each sample. This pool was then cleaned using UltraClean PCR Clean-Up Kit (MO BIO Laboratories, Inc.) and quantified using the Qubit (Invitrogen, Carlsbad, CA). After quantification, the molarity of the pool was determined and diluted to $2 \mathrm{nM}$, denatured, and then diluted to a final concentration of $4.0 \mathrm{pM}$ with a $10 \%$ PhiX spike for sequencing on the Illumina MiSeq via the protocol with $2 \times 150$ base pairs.

Sequence data were processed with the bioinformatic software QIIME 1.9.1 (Caporaso et al., 2010) using a 16S RDS pipeline (Nelson et al., 2014) with slight modifications. The subset of amplicon-based lineages identified as genera of known methanogens and methanotrophs (Appendix A, Table A1) were then further profiled for this study. Sub-samples were averaged to obtain one mean value for each section within each core.

\subsection{Ancillary measurements}

Data from nearby NOAA meteorological stations WBAN:14813 and WBAN:14985 (https://www.ncdc. noaa.gov/cdr, last access: 8 November 2018) were used to obtain hourly and daily averages of air temperature, precipitation, and atmospheric pressure. Eight dip wells adjacent to the peepers (Mat-N, Mat-S, Tamarack-N, Tamarack-S, Shrubs, Lagg, Res-N, and Res-S) were used for monthly measurements of water level. Water level was measured continuously between June 2017 and October 2018 in four of the eight dip wells (Mat-S, Tamarack-S, Shrubs, Res-S). Water levels at other locations were estimated based on an 
offset between manual readings of water level. To calculate water levels we used HOBO pressure sensors (Onset Computer Corporation, Bourne, MA) that were corrected using atmospheric pressure data from the NOAA stations. Adjacent to each peeper, we measured vertical profiles of dissolved oxygen two to four times a year using a probe equipped with a fiber-optic sensor and a temperature sensor (PreSens Precision Sensing GmbH, Regensburg, Germany). The probe was inserted to a depth of $80 \mathrm{~cm}$ and allowed to stabilize for ca. $30 \mathrm{~min}$. The probe was then moved upwards in $10-20 \mathrm{~cm}$ increments to complete a profile up to the level of the water table.

Water from the eight dip wells was sampled for chemical analysis roughly monthly between 27 June and 3 October 2017 in four sampling events. All dip wells were perforated at $60-90 \mathrm{~cm}$ below ground level to ensure that water samples were collected from a consistent depth. Before collecting water samples, dip wells were emptied completely using a vacuum syringe and allowed to refill. When it was impossible to completely empty a dip well due to rapid recharge, a volume of water equivalent to the volume of the dip well was removed before collecting samples. Electrical conductivity (EC) and $\mathrm{pH}$ were measured in the field using a YSI Pro1030 pH, conductivity, and salinity instrument. When dip-well recharge was insufficient for EC and $\mathrm{pH}$ measurements in the field, these measurements were made within $48 \mathrm{~h}$ in the lab using a YSI EcoSense EC30A conductivity and TDS pen tester and a YSI EcoSense EH10A pH and temperature pen tester. Water samples were then filtered using Whatman binder-free glass microfiber $0.7 \mu \mathrm{m}$ filters that had been combusted at $500^{\circ} \mathrm{C}$ to remove organic contamination. Water samples were stored in HDPE-coated bottles and frozen at $-22{ }^{\circ} \mathrm{C}$ for 10 months prior to analysis. Inductively coupled plasma-optical emission spectrometry (ICP-OES; US EPA, 2015b) was carried out using a Varian Vista-MPX to measure concentration of $\mathrm{Al}, \mathrm{Ca}, \mathrm{Fe}, \mathrm{K}, \mathrm{Mg}, \mathrm{Mn}, \mathrm{Na}, \mathrm{P}$, $\mathrm{S}$, and $\mathrm{Zn}$. Concentrations of $\mathrm{NO}_{3}+\mathrm{NO}_{2}$ nitrogen (measured as a combined value) and $\mathrm{NH}_{4}$ nitrogen were determined by colorimetry using Lachat's QuikChem ${ }^{\circledR} 8500$ Series 2 Flow Injection Analysis System (US EPA, 2015a). Quality assurance and quality control protocols were followed for both the ICP-OES and flow injection analyses. Recoveries of matrix spikes and serial dilutions were at least $75 \%$ and $90 \%$, respectively. The reporting limit (RL) for each batch of samples was the lowest concentration in the calibration curve. The $\mathrm{RL}$ for $\mathrm{NH}_{4}-\mathrm{N}$ was $0.1 \mathrm{mg} \mathrm{L}^{-1}$, and the $\mathrm{RL}$ for all other analytes was $0.01-0.05 \mathrm{mg} \mathrm{L}^{-1}$. Where concentrations were below the reporting limit, the measured concentration was substituted with one-half the reporting limit. Check standards and blanks were analyzed every 10 samples. Check standard recoveries did not exceed $\pm 10 \%$ error, and blanks did not exceed reporting limits. No blanks were allowed to exceed the reporting limits. Accuracy of $\mathrm{pH}$ and $\mathrm{EC}$ measurements was ensured through regular calibration of equipment.
In 27 June 2017, one core from the Shrubs zone and one from the Res zone were extracted for analysis of peat bulk density and porosity. The core was sliced every $2.5 \mathrm{~cm}$ to a depth of $50 \mathrm{~cm}$. Samples were packed and sealed in plastic bags and taken to the laboratory to measure wet weight. Samples were then dried in an oven at $60^{\circ} \mathrm{C}$ for $2-3 \mathrm{~d}$ until the weight was stable. Peat bulk density was calculated based on the weight of dry soil occupied by slices of $2.5 \mathrm{~cm} \times 12 \mathrm{~cm} \times 12 \mathrm{~cm}$. Porosity was calculated as $1 \mathrm{mi}-$ nus the ratio of peat bulk density to soil particle density, which was estimated as $1.45 \mathrm{Mg} \mathrm{m}^{-3}$ for Sphagnum peat soils (Oleszczuk and Truba, 2013).

\subsection{Data analysis}

Data preparation was completed in MATLAB (R2017b, Mathworks), and statistical analyses were completed in $\mathrm{R}$ version 3.5.1 (R Development Core Team, 2018). Differences in $\mathrm{CH}_{4}$ fluxes between hydro-biological zones were evaluated using a linear mixed-effect model $(\mathrm{lmm})$ through the function "Imer" implemented in $\mathrm{R}$ in the package "ImerTest" version 3.0-1 (Kuznetsova et al., 2017). Transformation of $\mathrm{CH}_{4}$ flux data to their logarithm base 10 was applied to improve the normality of the data and the normality of the residuals of the model. The fixed effects in the model were Zone (Water, Mat, Tamarack, Shrubs, and Res), a categorical value for year (Year), a categorical value for the month of measurements (Month), temperature $10 \mathrm{~cm}$ below the surface $\left(T_{\text {surf }}\right)$, mean water level for a month before the flux measurements (WLm), and a continuous variable representing the time to noon in hours (t2noon). The transect (north or south) was specified as a random effect. We also tested for the interactions between Zone and Month, Zone and $W L m$, and Zone and $T_{\text {surf }}$, but they were not significant. The final statistical model for both $\mathrm{CH}_{4}$ flux is described in Eq. (5):

$$
\begin{aligned}
\text { Flux } & \sim \text { Zone }+T_{\text {surf }}+\text { WLm }+ \text { Year }+ \text { Month } \\
& + \text { t2noon }+(1 \mid \text { Transect }) .
\end{aligned}
$$

Pair-wise differences in emissions among the zones were evaluated through testing differences in the marginal means of the reference grid of the mixed model using the package "emmeans" in R (Lenth et al., 2018). The overall effect of the factors within the model was evaluated with an ANOVA of the model. Significance in the model was defined with a $p$ value of 0.05 . To evaluate if plant fluxes were significantly different from zero, we used a one-sample Wilcoxon test.

Pore-water concentrations of $\mathrm{CH}_{4}$ were evaluated using a linear mixed model. We used a similar model to evaluate pore-water $\mathrm{CH}_{4}$ concentrations except that we added depth to the surface (Depth) as a fixed effect (see Eq. 6). We deleted the interaction between depth and zone because it was not significant. The final model for pore-water concentrations of 
$\mathrm{CH}_{4}$ is described in Eq. (6):

$$
\begin{aligned}
\mathrm{CH}_{4} \text { Pore-water conc. } & \sim \text { Zone }+ \text { Depth }+ \text { WLm }+T_{\text {surf }} \\
& + \text { Year }+ \text { Month }+(1 \mid \text { Transect }) .
\end{aligned}
$$

Pair-wise differences in pore-water concentrations between zones were tested by evaluating differences in the marginal means in the same way as for the model of $\mathrm{CH}_{4}$ flux. The overall effect of the factors in the model was evaluated with an ANOVA.

Chemical analyses were not included in the model, as chemistry data were only available for 2017 . Instead, a principal component analyses was run on the chemical variables (12 chemical species plus EC and $\mathrm{pH}$; Appendix A, Table A2) at the eight sampling locations, and the scores of the first principal component were correlated to mean $\mathrm{CH}_{4}$ fluxes, mean $\mathrm{CH}_{4}$ pore-water concentration, and mean $\mathrm{CH}_{4}$ transfer velocity. Differences in element concentrations between different vegetation zones and between different locations were evaluated using ANOVA. Pair-wise comparisons were evaluated using a Tukey HSD (honestly significant difference) post hoc test. Differences in peat bulk density were evaluated using an ANCOVA of zone and depth. The relationship between microbiota and methane fluxes was evaluated through a correlation of the ratio of the relative abundance of methanogens to the relative abundance of methanotrophs versus $\mathrm{CH}_{4}$ flux mean $\mathrm{CH}_{4}$ pore-water concentration and $\mathrm{CH}_{4}$ transfer velocity.

\section{Results}

\subsection{Inter- and intra-annual variation in abiotic conditions}

The mean air temperature during the growing season (1 May to 31 October) was $20.4^{\circ} \mathrm{C}$ in 2017 and $22.5^{\circ} \mathrm{C}$ in 2018 , as measured by standard meteorological stations. In 2017 and 2018, total precipitation for the growing season was 196 and $356 \mathrm{~mm}$, respectively (Fig. 2). The water level ranged from -45.4 to $19.7 \mathrm{~cm}$ in 2017 and -55.1 to $27.3 \mathrm{~cm}$ in 2018 , where negative levels indicate a water table below the ground surface (Fig. 2). As expected, the intermittently wetted area (Shrubs, Lagg, and Res zones) experienced substantial fluctuations in water level, while in the permanently wetted area (Tamarack) the water level remained at or close to the surface (Fig. 2). Fluctuations were smaller in the Tamarack zone, with the water table drawing down to a maximum depth of $12 \mathrm{~cm}$ compared to a maximum of $53 \mathrm{~cm}$ in the Shrubs (Fig. 2).

$\mathrm{pH}$ was similar throughout the bog, with higher values occurring in the restored (Res) zone than in the undisturbed zone (Appendix A, Table A2), but with no significant differences among the hydro-biological zones $(F=0.98, p=$ 0.43 ). The Lagg zone had significantly higher concentrations of $\mathrm{Fe}, \mathrm{Ca}, \mathrm{Mg}$, and $\mathrm{Mn}$ when compared to other hydro- biological zones ( $p<0.05$ for all paired relationships). The restored section had significantly higher concentration of $\mathrm{Mn}$ $(F=3.80, p=0.01)$ and $\mathrm{Na}(F=3.78, p=0.01)$. Concentrations of $\mathrm{Ca}$ and $\mathrm{P}$ tended to be higher in the restored section as well; however, the differences were not significant when comparing all hydro-biological zones $(F=2.88,2.47$; $p=0.05,0.07$; respectively). Interestingly, concentrations of ammonia $\left(\mathrm{NH}_{4}^{+}\right)$were significantly higher in the Tamarack zone $(F=10.6, p<0.001)$ than in all the other zones, while concentrations of nitrate $\left(\mathrm{NO}_{3}^{-}\right)$were generally low and did not significantly differ among zones $(F=0.05, p=0.91)$.

The northern section of the bog collected runoff from adjacent agricultural fields and, consequentially, had higher $\mathrm{pH}$, electrical conductivity, and concentration of elements including $\mathrm{S}, \mathrm{Na}, \mathrm{Mn}, \mathrm{Mg}, \mathrm{Fe}$, and $\mathrm{Ca}$ than the rest of the bog. Notably, when considering location-wise comparisons, the concentrations of $\mathrm{S}, \mathrm{Ca}$, and $\mathrm{Mn}$ were significantly higher in Tamarack-N than in all other locations of the undisturbed bog (Appendix A, Table A2). Location differences also occurred in the restored section. $\mathrm{pH}$ was significantly higher in the Res-N location $(p<0.05)$, and $\mathrm{P}$ was significantly higher in the Res-S location $(p<0.05)$.

Vertical profiles of dissolved oxygen confirmed the existence of anoxic conditions below the water level. Dissolved oxygen concentrations below the water level were always less than $0.1 \mathrm{mg} \mathrm{L}^{-1}$, whereas above the water level the concentration increased sharply. The only exception was the profiles taken at the Mat, which had an average dissolved oxygen concentration of $0.27 \mathrm{mg} \mathrm{L}^{-1}$.

Peat bulk density was significantly lower in the Shrubs than in the Res zone $(F=34.5, p<0.001)$, with averages \pm SD of $0.08 \pm 0.02$ and $0.12 \pm 0.03 \mathrm{~g} \mathrm{~m}^{-3}$, respectively. Calculated porosities assuming a peat particle density of $1.45 \mathrm{~g} \mathrm{~m}^{-3}$ (Oleszczuk and Truba, 2013) were equal to $94.5 \%$ and $91.8 \%$. Because the peat was saturated at the time of extraction this porosity is equivalent to the volumetric water content. There was not a significant effect of depth on peat bulk density ( $F=0.05, p=0.82$ ).

\subsection{The effect of different hydro-biological zones and water level on $\mathrm{CH}_{4}$ emissions}

There were higher $\mathrm{CH}_{4}$ emissions towards the central, permanently wetted part of the bog (Table 1). The fluxes from the Lagg zone were not significantly different than zero ( $t$ test, $p=0.185$ ) and were therefore excluded for future comparisons among zones. Mean $\mathrm{CH}_{4}$ fluxes were significantly different between hydro-biological zones $(F=1.14$, $p<0.001$ ). The fluxes from the Water zone were not significantly higher than the fluxes from the other units within the permanently wetted area $(t$ ratio $=-1.45, p=0.59$, and $t$ ratio $=1.27, p=0.70$, for Mat and Tamarack, respectively), but they were significantly higher than fluxes in the intermittently wetted area (Shrubs zone: $t$ ratio $=5.83, p<0.001$; Res zone: $t$ ratio $=6.53, p<0.001) . \mathrm{CH}_{4}$ emissions from 


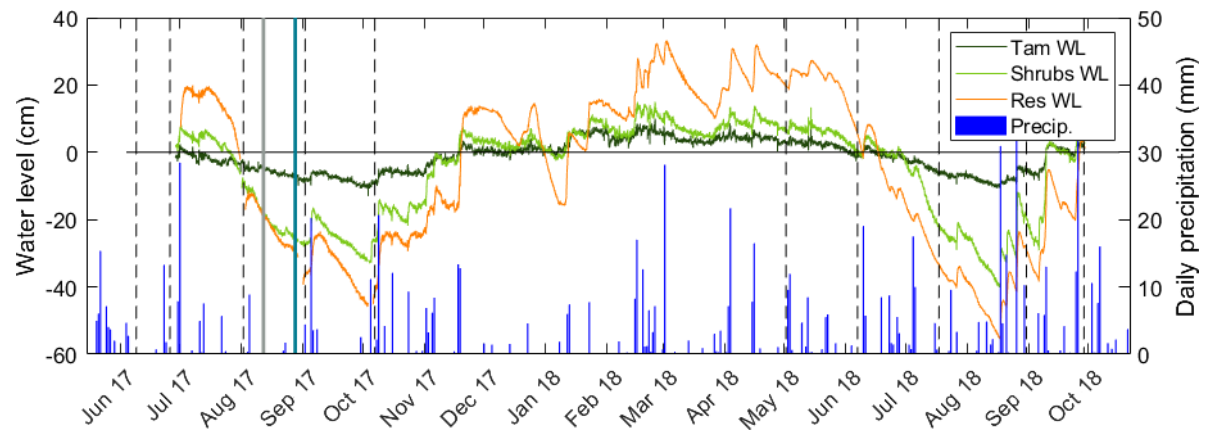

Figure 2. Water-level (WL) fluctuations in the tamarack mixed woodland (Tam) zone, the mixed ericaceous shrub (Shrubs) zone, and the restored (Res) zone of the bog. Vertical dashed lines indicated the 10 times of pore-water sampling, and the solid lines indicate the two times of core sampling: gray for Tam, Shrubs, and Res-S and teal for Mat and Res-N. The secondary axis shows daily values of precipitation.

Table 1. $\mathrm{CH}_{4}$ fluxes for the different hydro-biological zones in Flatiron Lake Bog. Integrated fluxes are based on a $122 \mathrm{~d}$ period for 2017 and $149 \mathrm{~d}$ period for 2018. Values in parenthesis for mean fluxes are the standard error and for the subsequent rows the propagated standard error.

\begin{tabular}{|c|c|c|c|c|c|}
\hline & $\begin{array}{l}\text { Area } \\
\left(\mathrm{m}^{2}\right)\end{array}$ & $\begin{array}{r}\text { Median flux } \\
\left(\text { nmol m }{ }^{-2} s^{-1}\right)\end{array}$ & $\begin{array}{r}\text { Mean flux } \\
\left(\text { nmol m}{ }^{-2} s^{-1}\right)\end{array}$ & $\begin{array}{r}\text { Daily normalized } \\
\text { emissions } 2017 \\
\left(\mathrm{mg} \mathrm{CH}_{4} \mathrm{~m}^{-2} \mathrm{~d}^{-1}\right)\end{array}$ & $\begin{array}{r}\text { Daily normalized } \\
\text { emissions } 2018 \\
\left(\mathrm{mg} \mathrm{CH}_{4} \mathrm{~m}^{-2} \mathrm{~d}^{-1}\right)\end{array}$ \\
\hline Water & 1119 & $\begin{array}{r}61.9 \\
(0.1-1823)\end{array}$ & $\begin{array}{l}122.6 \\
(24.5)\end{array}$ & $\begin{array}{r}349.2 \\
(402.5)\end{array}$ & $\begin{array}{r}210.7 \\
(169.8)\end{array}$ \\
\hline Mat & 927 & $\begin{array}{r}39.5 \\
(-12.2-753)\end{array}$ & $\begin{array}{r}82.5 \\
(20.7)\end{array}$ & $\begin{array}{r}154.1 \\
(86.9)\end{array}$ & $\begin{array}{r}83.2 \\
(48.5)\end{array}$ \\
\hline Tamarack & 14577 & $\begin{array}{r}10.5 \\
(-8.6-27186)\end{array}$ & $\begin{array}{r}602.2 \\
(342.1)\end{array}$ & $\begin{array}{r}68.6 \\
(82.8)\end{array}$ & $\begin{array}{r}2478.5 \\
(3819.5)\end{array}$ \\
\hline Shrubs & 85539 & $\begin{array}{r}3.1 \\
(-0.8-624)\end{array}$ & $\begin{array}{r}62.5 \\
(22.62)\end{array}$ & $\begin{array}{r}441.0 \\
(162.7)\end{array}$ & $\begin{array}{r}8.5 \\
(9.0)\end{array}$ \\
\hline Res & 23430 & $\begin{array}{r}0.7 \\
(-11.4-279.9)\end{array}$ & $\begin{array}{r}21.5 \\
(8.18)\end{array}$ & $\begin{array}{r}30.3 \\
(50.8)\end{array}$ & $\begin{array}{r}18.8 \\
(27.5)\end{array}$ \\
\hline $\mathrm{BB}^{\mathrm{a}}$ & 123546 & $\begin{array}{r}-0.4 \\
(-3.8 \text { to }-3.84)\end{array}$ & $\begin{array}{r}-1.1 \\
(0.47)\end{array}$ & $\begin{array}{l}-3.9 \\
(1.8)\end{array}$ & $\begin{array}{l}-3.8 \\
(1.3)\end{array}$ \\
\hline Total & 125592 & $\mathrm{n} / \mathrm{a}$ & $\mathrm{n} / \mathrm{a}$ & $\begin{array}{r}315.4^{\mathrm{b}} \\
(166)\end{array}$ & $\begin{array}{r}362.3^{\mathrm{b}} \\
(687)\end{array}$ \\
\hline
\end{tabular}

the restored section were significantly lower than the emissions from units in the permanently wetted area and the Mat $(t$ ratio $=-4.6, p<0.001)$ and Tamarack zones $(t$ ratio $=-6.1, p<0.001)$. However, $\mathrm{CH}_{4}$ emissions from the restored section were not significantly different from the emissions from the Shrubs zone ( $t$ ratio $=-0.17, p=0.99)$.

Mean water level (WLm) had a significant effect on $\mathrm{CH}_{4}$ flux $(F=8.49, p=0.003)$, with higher emissions occurring when WLm was more positive (higher WLm). The effect of water level on $\mathrm{CH}_{4}$ fluxes was not significant when considering instantaneous water levels at the time of the measurements but was significant when considering the average water-level data throughout the $30 \mathrm{~d}$ prior to the flux mea- surement. The effect of temperature $\left(T_{\text {surf }}\right)$ was not significant $(F=0.71, p=0.40)$.

\subsection{Temporal variations in $\mathrm{CH}_{4}$ fluxes}

There was a substantial temporal variability in $\mathrm{CH}_{4}$ fluxes. The open water zone was the only zone that had a distinct and consistent seasonal cycle, where the fluxes increased from May to the middle of the growing season, peaking in early September and declining in October (Fig. 3). In the Tamarack zone, fluxes declined over the growing season in 2017, but in 2018 the flux peaked in early September, where there were two extremely high flux measurements at the northern transect of 27180 and $8605 \mathrm{nmolm}^{-2} \mathrm{~s}^{-1}$ that skewed 


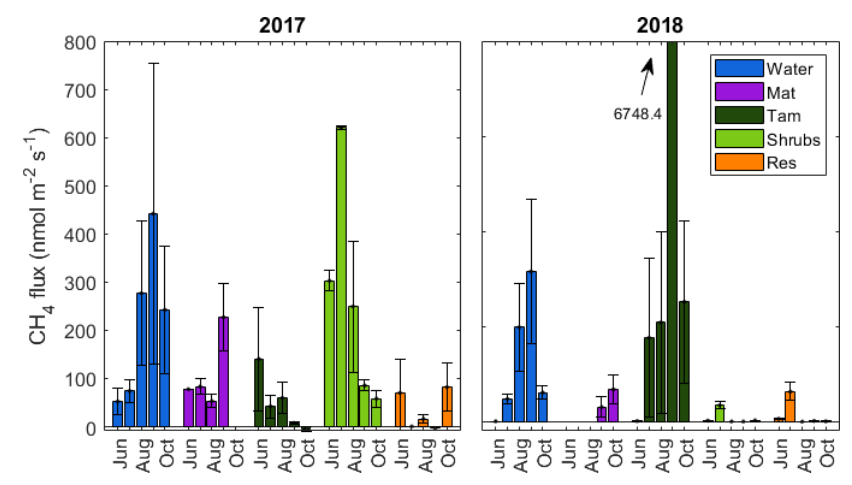

Figure 3. Monthly fluxes of methane for each of the five hydrobiological zones of the study. Fluxes from the Lagg were not significantly different than zero and are therefore not shown. Standard errors are for all sample locations within the same month and zone (variable number; see Sect. 2.3).

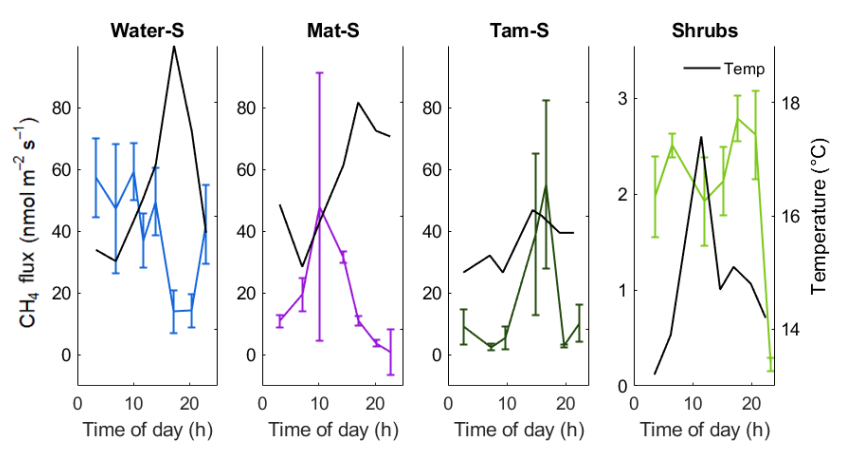

Figure 4. Diurnal patterns of $\mathrm{CH}_{4}$ emission measured over a $24 \mathrm{~h}$ period in September 2018. Note a smaller $y$ axis maximum in the Shrubs zone. Error bars represent the standard error of four individual chamber measurements within the same $30 \mathrm{~min}$ period at each location. Secondary axis (and black lines) shows the temperature at $10 \mathrm{~cm}$ below the surface either in the open water (Water) or in the peat (Mat, Tamarack, and Shrubs). The Res zone was not sampled.

the average to a total of $6748 \mathrm{nmolm}^{-2} \mathrm{~s}^{-1}$. There was no significant relationship between month of measurement and $\mathrm{CH}_{4}$ flux $(F=2.21, p=0.05)$. Across all hydro-biological zones, $\mathrm{CH}_{4}$ fluxes were not significantly different in 2017 and $2018(F=2.59, p=0.11)$.

Although the relationship of $\mathrm{CH}_{4}$ emissions with time to noon was significant $(F=13.1, p<0.001)$, the diurnal measurements from September 2018 (Fig. 4) did not indicate strong diurnal patterns of $\mathrm{CH}_{4}$ emissions. In the open water zone, $\mathrm{CH}_{4}$ emissions decreased during the late afternoon to early evening, which approximately coincided with a peak in water surface temperature (Fig. 4). In the Tamarack zone emissions increased with warmer temperatures in the afternoon. In the Mat zone there was a peak in the middle of the morning, but there was no apparent relationship with surface temperature. There was no clear diurnal pattern of $\mathrm{CH}_{4}$ emis-

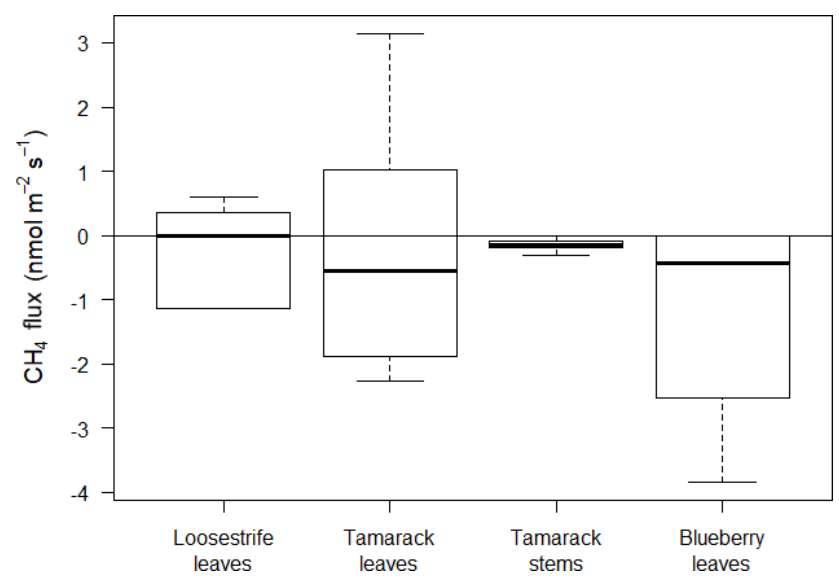

Figure 5. Plant-mediated $\mathrm{CH}_{4}$ fluxes from loosestrife leaves (Mat zone), tamarack leaves, tamarack Stems, and blueberry leaves (Tamarack and Shrubs zone). Only fluxes from the blueberry were significantly different from zero $(p=0.01)$.

sions in the Shrubs zone, likely a consequence of very low $\mathrm{CH}_{4}$ emissions during the time of measurements.

\subsection{Plants fluxes and upscaling of $\mathrm{CH}_{4}$ emissions}

Fluxes from plant tissues were negligible compared to the fluxes from the peat or open water surfaces (Fig. 5). Measurements from loosestrife, the most abundant vascular plant in the Mat, and from tamarack stems and stems were not significantly different from zero $(p=0.83, p=0.48$, and $p=0.06$, respectively). Fluxes from the blueberry leaves were significantly different than zero $(p=0.01)$ and averaged at $-1.11 \mathrm{nmolm}^{-2} \mathrm{~s}^{-1}$, indicating net uptake of $\mathrm{CH}_{4}$ by or through blueberry plants (Fig. 5).

The peat bog emitted a total of $4.8 \pm 1.9$ and $5.5 \pm 8.4 \mathrm{t}$ of $\mathrm{CH}_{4}$ during the growing seasons of 2017 and 2018, respectively. The high uncertainty in 2018 was due to the larger variation in fluxes produced by high fluxes in the Tamarack zone, which emitted a total of $0.12 \pm 0.14 \mathrm{t}$ of $\mathrm{CH}_{4}$ in 2017 but a much higher $5.4 \pm 8.2 \mathrm{t}$ of $\mathrm{CH}_{4}$ in 2018 .

Blueberry leaves acted as a slight sink of atmospheric $\mathrm{CH}_{4}$, with a mean flux of $-1.11 \mathrm{nmol} \mathrm{m}^{-2} \mathrm{~s}^{-1}$. The total sink of $\mathrm{CH}_{4}$ from blueberry bushes was equal to $-46.9 \pm 20$ and $-57.4 \pm 24 \mathrm{~kg}$ of $\mathrm{CH}_{4}$ for 2017 and 2018 , respectively. These values were equal to a small offset of the total daily emissions by $0.37 \%$ for 2017 and $0.14 \%$ for 2018 .

Because the length of the measurement periods in the growing seasons was not equal among years, total emissions (Table 1) were divided by the length of the measurement period to produce estimates of mean total flux per day. These values were then divided by the area of the bog (excluding the Lagg zone) to produce the final result of $315.4 \pm 166 \mathrm{mg} \mathrm{CH}_{4} \mathrm{~m}^{-2} \mathrm{~d}^{-1}$ in 2017 and $362.3 \pm$ $687 \mathrm{mg} \mathrm{CH}_{4} \mathrm{~m}^{-2} \mathrm{~d}^{-1}$ in 2018. 


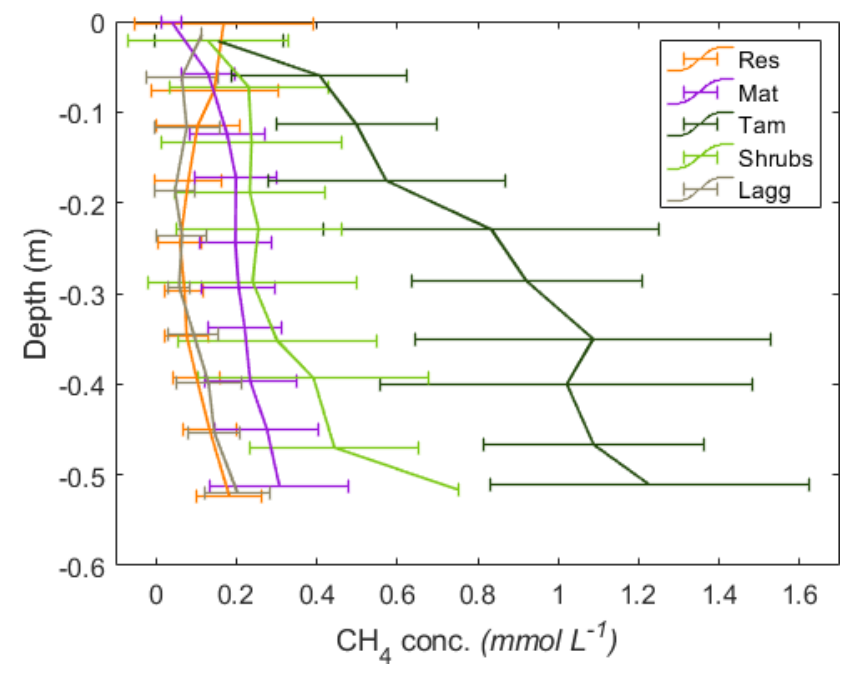

Figure 6. Vertical profiles of $\mathrm{CH}_{4}$ pore-water concentrations by zone. The error bars represent the standard deviation of the monthly measurements for 2017 and 2018 combined. A minor $y$-axis jitter has been added to more clearly distinguish zone patterns. Note that the concentrations in the Tamarack zone at depth approach saturation $\left(1.44 \mathrm{mM}\right.$ at $\left.20^{\circ} \mathrm{C} \mathrm{CH}_{4}\right)$.

\subsection{Dissolved $\mathrm{CH}_{4}$ pore-water concentrations and methane transfer velocity}

Excluding the Mat zone, the mean $\mathrm{CH}_{4}$ pore-water concentration per zone followed a pattern similar to the fluxes, with higher concentrations in the Tamarack zone, followed by Shrubs, Res, and Lagg zones (Fig. 6). Pore-water $\mathrm{CH}_{4}$ concentrations were significantly higher in the Tamarack zone than in the Mat zone $(t$ ratio $=3.3, p=0.003)$ and in the Shrubs zone $(t$ ratio $=6.4, p<0.001)$. Pore-water $\mathrm{CH}_{4}$ concentrations were significantly lower in the Res zone than in the Mat zone $(t$ ratio $=-7.2, p<0.001)$, the Tamarack zone $(t$ ratio $=-17.1, p<0.001)$, and the Shrubs zone $(t$ ratio $=$ $-6.8, p<0.001$ ) but not significantly different from concentrations in the Lagg $(t$ ratio $=0.28, p=0.77$; Fig. 6$)$. Differences in $\mathrm{CH}_{4}$ pore-water concentration between Mat and Shrubs zones were not significant $(t$ ratio $=1.98, p=0.19$ ). It is important to note that times for which the water table was below the level of a certain peeper sampling window were considered to be missing values because there was no pore water at that given height.

There was a significant relationship between $\mathrm{CH}_{4}$ concentration and depth $(F=85.3, p<0.001)$, with pore-water concentrations of $\mathrm{CH}_{4}$ increasing with depth. $\mathrm{CH}_{4}$ porewater increased significantly with increasing temperature $10 \mathrm{~cm}$ below the surface at the time of measurement $\left(T_{\text {surf }}\right)$ $(F=20.9, p<0.001)$ and with the average water level during the month preceding the measurement (WLm; $F=16.2$, $p<0.001$ ). Higher water tables were associated with increased $\mathrm{CH}_{4}$ pore-water concentration throughout the whole profile.
Per location, average (mean $\pm \mathrm{SD}$ ) $\mathrm{CH}_{4}$ pore-water concentration in the top $50 \mathrm{~cm}$ of the peat was the highest in Tamarack-S $(0.86 \pm 0.62 \mathrm{mM})$, followed by Tamarack-N $(0.76 \pm 0.36 \mathrm{mM})$, Shrubs $(0.30 \pm 0.26 \mathrm{mM})$, Mat-N $(0.21 \pm$ $0.12 \mathrm{mM})$, Mat-S $(0.19 \pm 0.12 \mathrm{mM})$, Res-N $(0.14 \pm 0.13 \mathrm{mM})$, Lagg $(0.10 \pm 0.08 \mathrm{mM})$, and Res-S $(0.09 \pm 0.08 \mathrm{mM})$. Ammonium concentration was positively correlated with $\mathrm{CH}_{4}$ porewater concentration averaged for the whole profile $\left(r^{2}=\right.$ $0.70, p=0.005)$ and for the top peat layer $\left(r^{2}=0.83, p<\right.$ $0.01)$.

$\mathrm{CH}_{4}$ pore-water concentrations were significantly different among months, with concentrations always lower in May ( $p<0.001$ for all paired relationships) and June $(p<0.001$ for all paired relationships) and higher in August, around the peak of the growing season, and October, at the end of the growing season. $\mathrm{CH}_{4}$ pore-water concentrations were significantly higher in 2018 than in $2017(F=24.9, p<0.001)$.

Overall, there was no significant relationship between average concentration and surface fluxes $\left(r^{2}<0.01, p=0.95\right)$, even when considering only the top layers of the peat column, where a better relationship was expected $\left(r^{2}=0.08\right.$, $p=0.11$; Fig. 7a). The lack of a relationship was surprising, as the values included only those times at which the top stratigraphic layer of the peat was saturated. Methane transfer velocity was calculated from these data (Fig. 7b) and from the times when the microbiology data were available for comparison (Fig. 7c).

The first principal component (PC1) of the chemical analytes explained $37.6 \%$ of the variation in the dataset, while the second explained $28.5 \%$ (Appendix B, Fig. B1). The 10 variables that contributed the most to $\mathrm{PC} 1$ were, in order, $\mathrm{Mn}, \mathrm{Ca}, \mathrm{Mg}, \mathrm{S}, \mathrm{P}, \mathrm{Al}, \mathrm{EC}, \mathrm{NA}, \mathrm{NO}_{3}$, and $\mathrm{K}$. There was no significant relationship between $\mathrm{PC} 1$ and $\mathrm{CH}_{4}$ flux $\left(r^{2}=\right.$ $0.17, p=0.17), \mathrm{CH}_{4}$ pore-water concentration $\left(r^{2}=0.15\right.$, $p=0.80)$, or $\mathrm{CH}_{4}$ transfer velocity $\left(r^{2}=0.12, p=0.65\right)$.

\subsection{Both methanogens and methanotrophs were more abundant in permanently wetted zones}

Overall, both methanogens and methanotrophs were at higher relative abundances (as a portion of the overall microbial communities) in the permanently wetted zones Mat$\mathrm{S}$ and Tamarack-S (where they accounted for $1.8 \%$ and $2.0 \%$ of the microbial communities, respectively, by amplicon percentages) than in the intermittently wetted zones Shrubs, Res-N, and Res-S $(0.2 \%, 0.1 \%$, and $0.1 \%$, respectively; Fig. 8). In addition, hydrogenotrophic methanogens (Methanobacterium and Methanoregula) were much more abundant than acetoclastic methanogens (Methanosaeta and Methanosarcina) at all sites (Fig. 8). Among the hydrogenotrophs, Methanobacterium was broadly present, while Methanoregula was generally a larger component of the methanogen community in saturated, undisturbed peat (Mat-S, Tamarack-S, and deep Shrubs). Among the acetoclastic methanogens Methanosaeta was observed only in the 

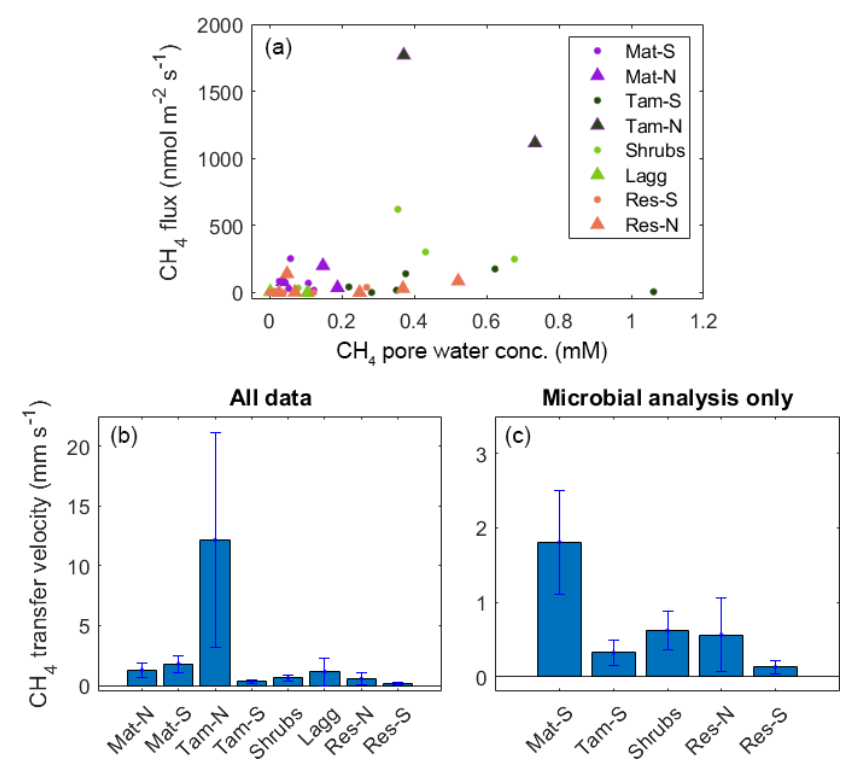

Figure 7. (a) Relationship between $\mathrm{CH}_{4}$ pore-water concentration and $\mathrm{CH}_{4}$ flux for times where the WL was high and within the top stratigraphic layer of the peat. (b) $\mathrm{CH}_{4}$ transfer velocity calculated from the upper plot; (c) same as previous, but with the data relevant for microbial analysis only. Note that microbial samples for Tam$\mathrm{N}$, Mat-S, and Lagg are not available and therefore not used in the following comparisons of $\mathrm{CH}_{4}$ transfer velocity against microbial activity. The error bars are the standard error.

permanently wetted zone Mat-S and Tamarack-S and accounted for a small proportion of total methanogens except at $50 \mathrm{~cm}$ in Mat-S. In the restored zones, where acetoclastic methanogens had higher relative abundances, the genus Methanosarcina was predominant.

Methanotrophs were mostly present in the permanently flooded zones Mat-S and Tamarack-S and were particularly abundant in peat strata closer to the surface $(0-20 \mathrm{~cm})$. Methylomonas accounted for most of the methanotroph sequences found in this study and dominated the methanotrophs of the Mat-S and Tamarack-S zones, while Methylosinus was a much larger portion of the methanotrophs in the Shrubs and Res zones (Fig. 8) even as overall methanotroph relative abundance dropped to less than $0.05 \%$ of the microbial community.

Methane fluxes were not correlated to the relative abundance of methanogens $\left(r^{2}=0.01, p=0.74\right)$ or methanotrophs $\left(r^{2}=0.01, p=0.78\right)$. In addition, mean $\mathrm{CH}_{4}$ concentrations were also not correlated to the relative abundance of methanogens $\left(r^{2}=0.01, p=0.83\right)$ or methanotrophs $\left(r^{2}=0.01, p=0.70\right)$. However, for the principal coordinates analysis of sites based on geochemistry, PC1 was significantly negatively correlated to methanogens' relative abundance $\left(r^{2}=0.90, p<0.01\right)$. As indicated above, most of the variation in $\mathrm{PC} 1$ was driven by $\mathrm{Mn}, \mathrm{Ca}, \mathrm{Mg}$, and $\mathrm{S}$, and there was a significant relationship between mean methanogen relative abundance and manganese $\left(r^{2}=0.90\right.$, $p=0.007)$ and sulfur concentrations $\left(r^{2}=0.74, p=0.03\right)$. When considering only the bottom $25 \mathrm{~cm}$ of the peat profile, the layer from which pore water was taken for chemical analyses, methanogen relative abundance was negatively correlated to electrical conductivity $\left(r^{2}=0.85, p=0.01\right)$. In the top layer of the peat, where methanotrophs are more active, there was a negative correlation between methanotroph relative abundance and magnesium concentration $\left(r^{2}=0.79\right.$, $p=0.03)$.

\section{Discussion}

\subsection{The $\mathrm{CH}_{4}$ budget and its heterogeneity among hydro-biological zones}

There were relatively high $\mathrm{CH}_{4}$ emissions in Flatiron Lake Bog compared to previously reported fluxes in other northern peatlands. Average daily $\mathrm{CH}_{4}$ emissions were equal to $315.4 \pm 166 \mathrm{mg} \mathrm{CH}_{4} \mathrm{~m}^{-2} \mathrm{~d}^{-1}$ in 2017 and $362.3 \pm$ $687 \mathrm{mg} \mathrm{CH}_{4} \mathrm{~m}^{-2} \mathrm{~d}^{-1}$ in 2018 . These values were higher than emissions in ombrotrophic peat bogs in Minnesota (monthly average range: $27-240 \mathrm{mg} \mathrm{CH}_{4} \mathrm{~m}^{-2} \mathrm{~d}^{-1}$; Chasar et al., 2000; $117 \mathrm{mg} \mathrm{CH}_{4} \mathrm{~m}^{-2} \mathrm{~d}^{-1}$; Dise, 1993) and Michigan (0.6-209 $\mathrm{mg} \mathrm{CH}_{4} \mathrm{~m}^{-2} \mathrm{~d}^{-1}$; Shannon and White, 1994) and in a boreal bog in northern Quebec $\left(57 \mathrm{mgCH}_{4} \mathrm{~m}^{-2} \mathrm{~d}^{-1}\right.$; Nadeau et al., 2013). Higher $\mathrm{CH}_{4}$ fluxes compared to other bogs are likely the result of the higher temperatures experienced in Ohio, which are at the southern limit of northern peatland distribution.

Methane fluxes were highly heterogeneous, with a variation of over 4 orders of magnitude and with a skewed distribution due to extreme events of $\mathrm{CH}_{4}$ flux (median: $33.7 \mathrm{nmol} \mathrm{m}^{-2} \mathrm{~s}^{-1}$; range: $\quad-12.2-27186 \mathrm{nmol} \mathrm{m}^{-2} \mathrm{~s}^{-1}$ ). The skewed distribution of $\mathrm{CH}_{4}$ fluxes and heterogeneity has also been found by Christen et al. (2016) in a Canadian undisturbed scrub-pine Sphagnum bog (median: $42 \mathrm{nmolm}^{-2} \mathrm{~s}^{-1}$; range: $5-3500 \mathrm{nmolm}^{-2} \mathrm{~s}^{-1}$ ) and by Treat et al. (2007) in temperate fen in New Hampshire (range: $6.3-2772 \mathrm{nmol} \mathrm{m}^{-2} \mathrm{~s}^{-1}$ ). We found higher emissions in the open water (mean: 122; median: 61.9; range: $0.14-1823 \mathrm{nmol} \mathrm{m}^{-2} \mathrm{~s}^{-1}$ ) than in the other hydro-biological zones. This pattern was also found by Christen et al. (2016), who found that fluxes from open waters or ponds had an average of $3336 \mathrm{nmolm}^{-2} \mathrm{~s}^{-1}$ and a median value of $2670 \mathrm{nmol} \mathrm{m}^{-2} \mathrm{~s}^{-1}$ compared to collars on the ground containing vegetation that had mean and median values of 986 and $47 \mathrm{nmolm}^{-2} \mathrm{~s}^{-1}$, respectively. In an analysis of a variety in peatlands in Minnesota, Crill et al. (1988) also found that mean $\mathrm{CH}_{4}$ emissions were $294 \mathrm{mg} \mathrm{m}^{-2} \mathrm{~d}^{-1}$ in open bogs, while in forested bogs the mean was equal to $77 \mathrm{mg} \mathrm{m}^{-2} \mathrm{~d}^{-1}$. This result agrees with our calculations, where we find daily normalized fluxes averaged 
(a) Methanogen and methanotroph relative abundance (\%)

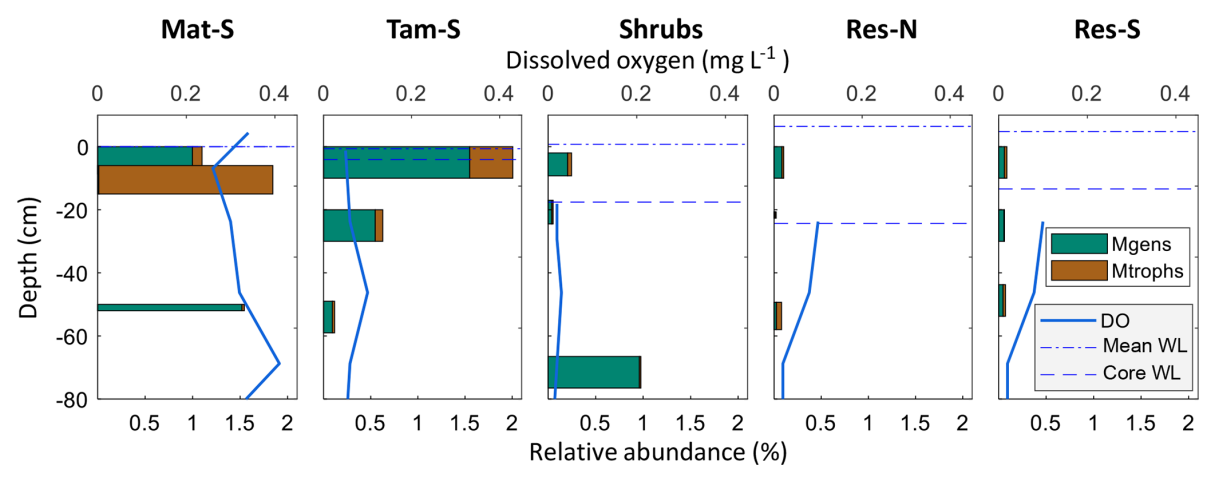

(b) Methanogen relative abundance (\%) (zoomed in)
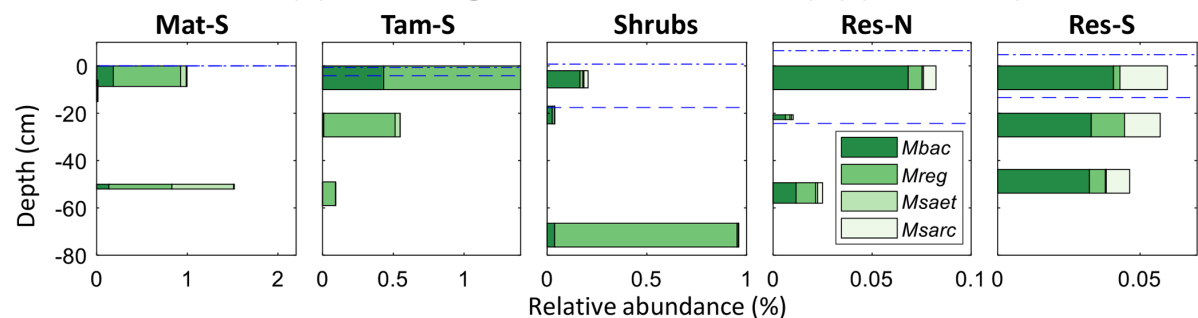

(c) Methanotroph relative abundance (\%) (zoomed in)
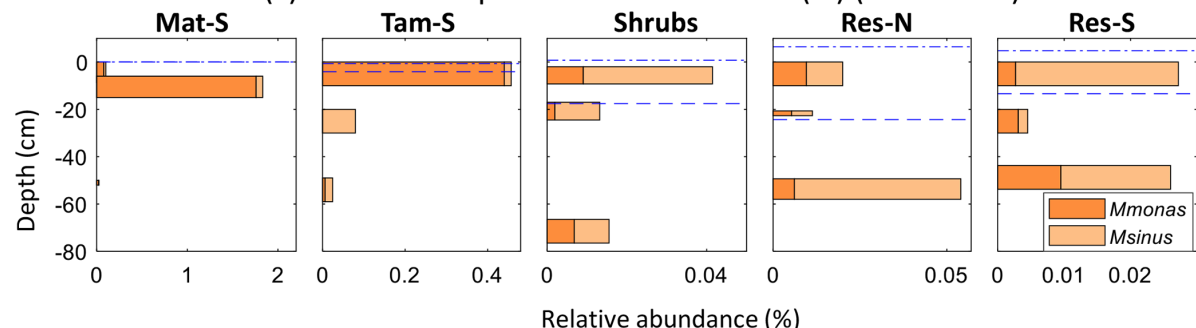

Figure 8. Relative abundances of methanogens and methanotrophs in the Mat-S, Tam-S, Shrubs, Res-N, and Res-S zones of the bog at different depths in the peat column, with the mean water level from June 2017 through August 2017 (mean WL) and the water level at time of sampling (core WL; in Mat-S these were both at $0 \mathrm{~cm}$; in Tam-S, the mean WL was at $0 \mathrm{~cm}$ ). Panel (a) shows overall methanogen (Mgens) and methanotroph (Mtrophs) abundances along with the average dissolved oxygen profile over the preceding month (from coring; see Methods). The observed genera of methanogens and methanotrophs are shown in panels (b) and (c), respectively, with variable $x$ axes. Methanobacterium (Mbac) and Methanoregula (Mreg) are hydrogenotrophic methanogens, and Methanosaeta (Msaet) and Methanosarcina (Msarc) are acetoclastic methanogens. Methylomonas (Mmonas) and Methylosinus (Msinus) are methanotrophs.

for both years of $279 \mathrm{mgCH}_{4} \mathrm{~m}^{-2} \mathrm{~d}^{-1}$ in open water and $224.72 \mathrm{mgCH}_{4} \mathrm{~m}^{-2} \mathrm{~d}^{-1}$ in the mixed ericaceous shrub units.

There were extremely high $\mathrm{CH}_{4}$ flux measurements from the northern transect of the Tamarack zone in September 2018 (27 180 and $\left.8605 \mathrm{nmol} \mathrm{m}^{-2} \mathrm{~s}^{-1}\right)$ and in October 2018 ( 2808 and $6609 \mathrm{nmol} \mathrm{m}^{-2} \mathrm{~s}^{-1}$ ). These measurements were not ebullition events, since the increase in concentration with time was steady (Appendix B, Fig. B2) and the coefficient of correlation for both flux events was higher than 0.97 . They were not localized events either, since the two collars were about $1.5 \mathrm{~m}$ apart from each other. Unfortunately, a core was not taken at the northern transect where this event occurred, so the abundance of methanogens and methanotrophs could not be tested. Interestingly, the concen- tration of sulfur was significantly higher in this zone, indicating that the Tamarack-N possesses an environment that is highly reduced where both methanogenesis and sulfate reduction take place at extremely high rates. This was corroborated by the detection of a potent smell of hydrogen sulfide while measuring these extremely high $\mathrm{CH}_{4}$ fluxes. It is also possible that specific plant-soil relationships, such as higher polysaccharides in the form of tree-root exudates (Lai, 2009), have enhanced $\mathrm{CH}_{4}$ production in the Tamarack zone. However, more research on the characteristics of the peat at this site is needed to reach conclusions about these extreme events.

Although higher heterogeneity in $\mathrm{CH}_{4}$ fluxes within peat bogs can be encountered, it is likely that the same patterns 
of $\mathrm{CH}_{4}$ flux along hydro-biological zones occur in other kettle-hole peat bogs due to the tight relationships between water-level fluctuations and vegetation composition in these ecosystems (Malhotra et al., 2016). It is also possible that the higher rates of $\mathrm{CH}_{4}$ emission in this Ohio peat bog are replicated in similar peat bogs located at lower latitudes, where warmer temperatures have the potential to not only drive much higher productivity (Cai and $\mathrm{Yu}, 2011$ ) but also increase methane emissions due to the effect of higher temperatures on $\mathrm{CH}_{4}$ emissions in peatlands (Moore and Dalva, 1993; Pugh et al., 2018).

\subsection{The role of plants in the $\mathrm{CH}_{4}$ cycle in peat bogs}

The presence of different plant species was strongly associated with variations in $\mathrm{CH}_{4}$ emissions in peatlands. For example, the presence of sedges, such as Eriophorum vaginatum L., in ombrotrophic peat bogs was observed to be an important transport of $\mathrm{CH}_{4}$ to the atmosphere (Greenup et al., 2000). In our study site, however, there was no active plant transport of $\mathrm{CH}_{4}$. This lack of plant transport in ombrotrophic peat bogs has also been reported by Chasar et al. (2000) and can be likely attributed to a low abundance of sedges.

Lai et al. (2014) found that fluxes varied significantly among plant communities at the ombrotrophic Mer Bleue bog in Canada. In this bog, low fluxes were found in Chamaedaphne (32-22 $\mathrm{mgCH}_{4} \mathrm{~m}^{-2} \mathrm{~d}^{-1}$ ) and $M a$ ianthemum and Ledum (83-53 $\mathrm{mg} \mathrm{CH}_{4} \mathrm{~m}^{-2} \mathrm{~d}^{-1}$ ) communities, whereas the highest were found in the Eriophorumdominated community $\left(122-124 \mathrm{mgCH}_{4} \mathrm{~m}^{-2} \mathrm{~d}^{-1}\right)$. The magnitude of these fluxes was much lower than the average daily emissions from the mixed ericaceous shrubs of $224.72 \mathrm{mg} \mathrm{CH}_{4} \mathrm{~m}^{-2} \mathrm{~d}^{-1}$.

Interestingly, we found that blueberry plants were slight but statistically significant sinks of $\mathrm{CH}_{4}$. This result was also reported by Sundqvist et al. (2012), who found that boreal plants of spruce (Picea abies), birch (Betula pubescens), rowan (Sorbus aucuparia), and pine (Pinus sylvestris) showed a net uptake of $\mathrm{CH}_{4}$. The values found by Sundqvist et al. (2012) fluctuated between 1 and $2 \mathrm{nmol} \mathrm{m}^{-2} \mathrm{~s}^{-1}$, which is similar to the values found in this study. The mechanism behind this process is still uncertain, but it has been reported that this process could be mediated by epiphytic bacteria capable of consuming $\mathrm{CH}_{4}$ (Raghoebarsing et al., 2005). Sundqvist et al. (2012) believe that the response is mediated by gross primary productivity and stomatal conductance through mechanisms not yet understood.

We did not find a clear diurnal pattern of $\mathrm{CH}_{4}$ emissions in the bog. Similarly, summer season measurements of eddy covariance in an ombrotrophic bog did not find clear diurnal patterns either (Nadeau et al., 2013). In contrast, studies in other wetlands have found a mid-morning peak in $\mathrm{CH}_{4}$ emissions in fen (Whiting and Chanton, 1992) and marshes (Kim et al., 1999; Rey-Sanchez et al., 2018; Van der Nat et al., 1998). This discrepancy is likely due to the fact that $\mathrm{CH}_{4}$ emissions in marshes (Chu et al., 2014; Hatala et al., 2012; Morin et al., 2014, 2017), and in fen (Chasar et al., 2000; Treat et al., 2007; Waddington and Day, 2007), are largely dominated by plants that transport $\mathrm{CH}_{4}$ through their aerenchyma.

\subsection{Fluctuations in water level explain variability in $\mathrm{CH}_{4}$ emissions}

Methane fluxes were different among hydro-biological zones, but given that plants were not a pathway of $\mathrm{CH}_{4}$ flux, the reported differences were most likely driven by the waterlevel differences among hydro-biological zones. The length of dry conditions preceding permanently wetted conditions has important consequences for the magnitude of $\mathrm{CH}_{4}$ fluxes (Turetsky et al., 2014). While the highest $\mathrm{CH}_{4}$ flux occurs after a period of $30 \mathrm{~d}$ of antecedent wet conditions (Turetsky et al., 2014), longer dry periods reduce the capacity of methanogens to acclimate to stable environmental conditions, therefore reducing methanogenesis. Indeed, we found that the average water-level data throughout the $30 \mathrm{~d}$ prior to the flux measurement, not the instantaneous water level, had a significant effect in $\mathrm{CH}_{4}$ fluxes. We hypothesize that this is a general ecological response by which community composition lags behind environmental change. In our case, it may take several weeks for methanogens to acclimate to new water levels after the water level has been raised, therefore not responding to instantaneous changes in water level. Both Res and Shrubs zones were characterized by high fluctuations in water level, which was likely the cause of lower $\mathrm{CH}_{4}$ emissions in these zones when compared to the more permanently wetted Tamarack, Mat, and Water zones. Higher WL fluctuations in the Shrubs zones in 2018 (range: -40.4-6.1 cm) than in 2017 (range: $-31.6-8.0 \mathrm{~cm}$ ) could also explain the higher $\mathrm{CH}_{4}$ emissions in 2017 than in 2018 in the Shrubs zone.

Our conclusion is that methanogen inhibition associated with longer dry periods in the Shrubs and Res zones is likely the cause of lower $\mathrm{CH}_{4}$ emissions. However, reduced $\mathrm{CH}_{4}$ emissions are also the result of an increase in the amount of methanotrophy in the upper, oxic layers. We can confirm this, as we observed pore-water concentrations of $\mathrm{CH}_{4}$ that were much higher in the Shrubs zone than in the Res zone despite similar WL fluctuation. Yet the fluxes were not significantly different between these two zones, indicating higher levels of methanotrophy in the Shrubs zones. Indeed, methanotroph relative abundance in the top section was twice as much in the Shrubs zone than in the Res zone.

We did not find a significant correlation between $\mathrm{CH}_{4}$ flux and surface temperature. This is partially explained by the fact that the effect of temperature on peatland $\mathrm{CH}_{4}$ emissions is significant when the water table is near the surface (Strack and Zuback, 2013), and our site had significant water-level fluctuations. For example, Lai et al. (2014) found that the relationship between temperature and $\mathrm{CH}_{4}$ flux was only sig- 
nificant when the water table was less than $30 \mathrm{~cm}$ depth in average. It is possible that due to monthly variations in the water level in the Shrubs and Tamarack sites, the response of $\mathrm{CH}_{4}$ emissions to temperature was confounded. The temporal resolution of the measurements was also a reason for the lack of correlation. At a higher temporal resolution, such as the measurements of the diurnal pattern, the effect of temperature on $\mathrm{CH}_{4}$ emissions may be more easily discerned.

\subsection{Pore-water $\mathrm{CH}_{4}$ concentrations were higher in the undisturbed section}

Pore-water $\mathrm{CH}_{4}$ concentration was high throughout the undisturbed section of the bog and significantly lower in the restored section. Although concentrations of key electron acceptors, such as nitrates or sulfates, were low and not significantly different among zones, we found that the restored section had significantly higher concentration of $\mathrm{Mn}$ $(F=3.80, p=0.01)$ and $\mathrm{Na}(F=3.78, p=0.01)$, suggesting that bacterial manganese reduction could compete against methanogens in the restored zone.

Excluding the Mat zone, pore-water $\mathrm{CH}_{4}$ concentration followed a similar pattern of variation to the fluxes, with higher concentrations in the Tamarack zone followed by Shrubs, Res, and Lagg zones. Low concentrations but higher fluxes in the Mat zones indicate a higher $\mathrm{CH}_{4}$ transfer velocity. This could be the consequence of different porosities in the peat that affect the rate of transfer. However, because the porosity throughout the peat bog was uniform, it is likely that $\mathrm{CH}_{4}$ transfer velocity is being driven by microbial activity rather than physical properties (see Sect. 4.6).

Pore-water $\mathrm{CH}_{4}$ concentration was the highest in the Tamarack zone, with concentration at deeper levels close to the saturation point $(1.2 \mathrm{mM})$. Similarly, in a study in an ombrotrophic peat bog in Minnesota, Chasar et al. (2000) reported high $\mathrm{CH}_{4}$ pore-water concentrations in bogs of 1.2 and $1.5 \mathrm{mM}$ for pore water at about $1 \mathrm{~m}$ of depth for June and July, respectively. Chasar et al. (2000) also reported much higher pore-water $\mathrm{CH}_{4}$ concentrations in bogs than in fen and suggested that this is related to negligible plant transport in peat bogs that causes $\mathrm{CH}_{4}$ to accumulate in the pore water, diffuse upwards, and be oxidized in the top layers of the peat. Methanotrophy in the shallow layers of the peat was also reported by Chasar et al. (2000), where analysis of isotopes in shallow pore water versus associated fluxes indicated oxidation of $\mathrm{CH}_{4}$ in the pore water before diffusive transport to the atmosphere.

Concurrent measurements of pore-water $\mathrm{CO}_{2}$ concentrations indicated that the $\mathrm{CH}_{4}: \mathrm{CO}_{2}$ ratio was similar at the top of the profiles, while at the bottom of the profiles there was a clear difference between restored and undisturbed sites (Appendix B, Fig. B3). This difference could indicate that there is a higher competition for respiratory processes in the disturbed section, while methanogenesis is more favored in the undisturbed section. The analysis of $\mathrm{CO}_{2}$ fluxes is not, how- ever, within the scope of this paper and is presented here only as a preamble for future studies.

\subsection{Methane-cycler abundance depends on vegetation zone and water level}

Consistent with expectations based on their anaerobic lifestyle, we found higher relative abundances of methanogens in the permanently wetted areas Mat and Tamarack than in the intermittently wetted areas (Shrubs, Res$\mathrm{N}$, and Res-S). Hydrogenotrophic methanogens, which are typically dominant in nutrient-poor sites (Kelly et al., 1992; Kim et al., 2008; Kotsyurbenko et al., 2004) and are typical of Sphagnum-dominated bogs (Chasar et al., 2000; Kelly et al., 1992; Lansdown et al., 1992), dominated both the undisturbed and restored sections, while acetoclastic methanogens were rare and only slightly more common in the restored section. We hypothesized that the restored section had gained more nutrients due to higher degree of mineralization; however, the dominance of hydrogenotrophic methanogens suggests that the restored section may still be nutrient-poor, despite the disturbance and apparent mineralization of the soil. This is also evident in the low concentration of key constituents, such as nitrates, iron, ammonium, phosphorous, and magnesium (although note relatively higher concentrations of manganese and calcium in the restored section; Appendix A, Table A2). It is possible that 15 years of restoration efforts have effectively restored this section's trophic status and that acetoclastic methanogenesis was higher there in the past. Alternately, the original disturbance may have had minimal impact on the microbial composition such that the restored section retains a community similar to its predisturbance state, when it was part of the Shrubs zone of the then-undisturbed section. Basiliko et al. (2013) similarly found that mining-based disturbance and subsequent restoration of Canadian peatlands did not affect archaeal microbial community composition.

At the genus level, however, there were differences in methanogen composition between the undisturbed and restored sections. While hydrogenotrophic genera strongly dominated both, there was a shift from Methanoreguladominated communities in the undisturbed sections to strongly Methanobacterium-dominated communities in the restored sections. Based on our prediction of a higher nutrient status in the restored site, we would have expected the opposite trend in Methanoregula dominance, since Methanomicrobiales (the order containing Methanoregula) have been observed as preferring nutrient-rich sites (Godin et al., 2012); their dominance is further indication that the restored section is not as high in nutrients as we expected. In contrast to the hydrogenotrophs, the acetoclastic methanogens did not show genus-level differences from undisturbed to restored zones but rather from inundated (Mat-S and Tamarack-S) to intermittently flooded (Shrubs, Res-N, and Res-S) ones. When acetoclastic methanogens were present, Methanosaeta 
dominated their community, consistent with observations of Methanosaeta in nutrient-poor acidic sites (Godin et al., 2012). However, in the inundated zones, Methanosarcina was also present. This is actually the opposite pattern we would have expected based purely on likely oxygen concentrations, as Methanosaeta typically dominates anaerobic environments while Methanosarcina can produce methane under partially oxic conditions (Angel et al., 2011). We therefore interpret Methanosaeta's presence in FSL-S and TMW-S to arise from its greater metabolic versatility - in addition to acetate, it can also use $\mathrm{CO}_{2}$ or methylated compounds (Liu and Whitman, 2008) - and thus conclude that these sites may have distinct substrate profiles.

Methanotrophic lineages, like methanogens, were at the highest relative abundances in the undisturbed, inundated sites, where they primarily occurred near the peat surface. The higher abundance of methanotrophs in inundated zones may be related to the presence of Sphagnum mosses in these zones, as methanotrophs are a common, abundant member of the Sphagnum microbiome (Dedysh, 2011; Kostka et al., 2016); the DNA extraction method may have accessed microbiota on and within the moss as well as from the bulk peat. Alternatively the higher methanotrophs in the inundated sections may have been in the bulk peat and may simply be due to the higher supply of methane in those areas.

\subsection{Microbiota drive $\mathrm{CH}_{4}$ transfer velocity}

While methanogens control the production of $\mathrm{CH}_{4}$ through the peat column, methanotrophs interact with plants and physical processes to mediate the portion of produced $\mathrm{CH}_{4}$ that is oxidized before being emitted to atmosphere. We therefore examined the relationship between resident $\mathrm{CH}_{4}$ cyclers and the $\mathrm{CH}_{4}$ transfer velocity in the top stratigraphic layer of the peat. Generally, when the water level is near the surface, $\mathrm{CH}_{4}$ diffuses directly from the surface pore water to the overlying air and can also be transported via plant tissue. However, at our site, we measured no significant $\mathrm{CH}_{4}$ transport through vascular plants (see Sect. 4.2). Therefore, the transport pathway at the upper layers of the soil in all zones (except Water) should occur through the ubiquitous Sphagnum mat and thus have similar resistance throughout the site. We also found no significant correlation between $\mathrm{CH}_{4}$ pore-water concentration at the top soil layers and surface $\mathrm{CH}_{4}$ flux (Fig. 7a). Thus, with all zones expected to be similar in their physical transport processes, observed differences in $\mathrm{CH}_{4}$ transfer velocity among zones should represent differences in microbial processes. Indeed, we found a significant correlation between $\mathrm{CH}_{4}$ transfer velocity and the ratio of total methanogens to total methanotrophs $\left(r^{2}=0.33\right.$, $p=0.03$; based on the relative abundances of lineages in each functional guild, see Methods; Fig. 9). A related result was reported in a rice paddy system, where the ratio of the gene expression of the two diagnostic marker genes for methanogenesis and methanotrophy, mcrA and pmoA, in

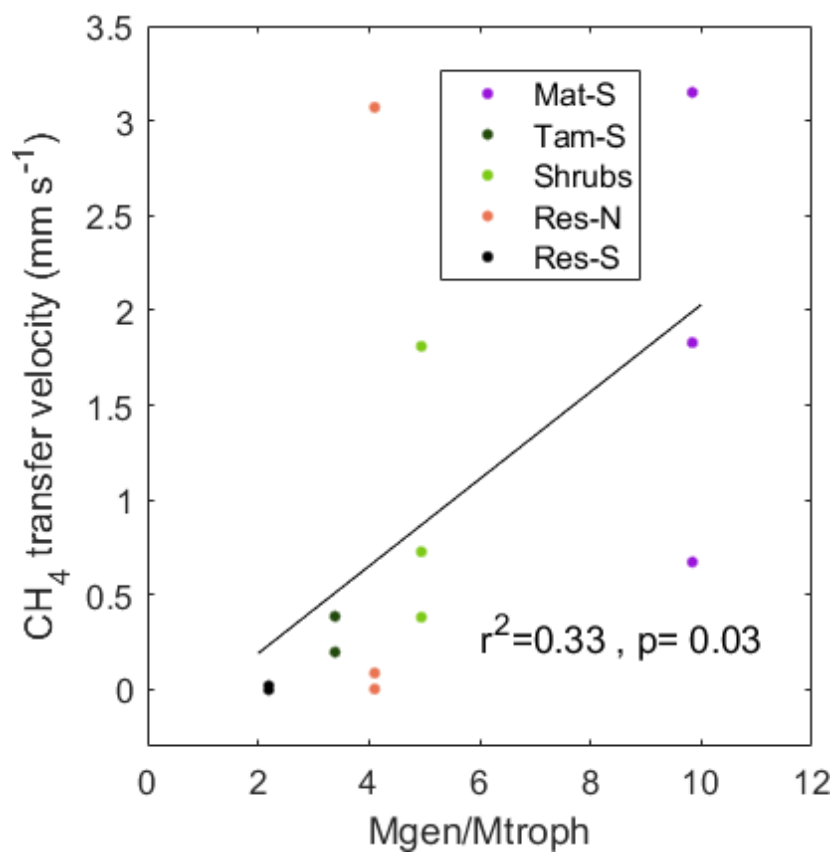

Figure 9. Relationship between the ratio of the relative abundance of methanogenic-methanotrophic lineages (Mgen/Mtroph) and the $\mathrm{CH}_{4}$ transfer velocity in the top stratigraphic layer of the peat profile: $0-6.7 \mathrm{~cm}$ for Mat and $0-12.5 \mathrm{~cm}$ for the other zones. $\mathrm{CH}_{4}$ transfer velocity was calculated as the average for the 3 months prior to coring, during which the water level was within or above the top stratigraphic layer.

the upper $10 \mathrm{~cm}$ of the soil was highly correlated to $\mathrm{CH}_{4}$ flux (Lee et al., 2014). However, in our site, this correlation was not significant when using $\mathrm{CH}_{4}$ flux data alone $\left(r^{2}=0.01, p=0.75\right)$ or pore-water data alone $\left(r^{2}=0.03\right.$, $p=0.57)$. It is intriguing that, despite the fact that presence does not necessarily imply activity, and relative abundances do not represent absolute abundances, in our study we see this relationship between the 16S rRNA gene amplicons of known methanogenic and methanotrophic lineages and the $\mathrm{CH}_{4}$ fluxes in both undisturbed and restored peatlands. This result illustrates the utility of examining microbiota to explain differences between $\mathrm{CH}_{4}$ production and emissions to the atmosphere.

\section{Conclusions}

Flatiron Lake Bog had high rates of $\mathrm{CH}_{4}$ emission that included several extreme fluxes from the Tamarack mixed woodland zone that were not driven by ebullition. $\mathrm{CH}_{4}$ emissions decreased with distance from the center of the bog, from regularly wetted sections to those that had higher waterlevel fluctuations. Pore-water concentrations followed a similar pattern of increase with depth, except for the Mat zone, which is adjacent to the open water and thus has better vertical mixing. Longer dry periods in the Shrubs and Res 
zone likely inhibited methanogens, lowering their abundance and thus decreasing $\mathrm{CH}_{4}$ accumulation in the pore water and associated emissions. Although pore-water chemistry explained some of the variation in pore-water $\mathrm{CH}_{4}$ concentration, water level explained the largest component of variation in $\mathrm{CH}_{4}$ fluxes due to its effects on methanogenesis and methanotrophy at the top soil levels. Given that plants were not an appreciable pathway of $\mathrm{CH}_{4}$ flux, the reported differences in $\mathrm{CH}_{4}$ transfer velocity when the water level was high were explained by the ratio of the relative abundance of methanogens to methanotrophs in the top layer.

Why would two locations with similar near-surface $\mathrm{CH}_{4}$ concentrations have different fluxes if they also have similar diffusivities and negligible ebullition and plant transport? Our results show that the answer is that they have different transfer velocities for $\mathrm{CH}_{4}$. Transfer velocities are normally a function of wind speed, but beneath the shrub and tree canopy of peat bogs wind speeds are very low, so something else is affecting this transfer velocity. The upper layer of the bog's peat mass is a dynamic region with both methanotrophs and methanogens living within the oxic layer (Angle et al., 2017). Within this layer, higher abundance of methanogens drives higher transfer velocities if the concentration of $\mathrm{CH}_{4}$ is assumed to be at a quasi-steady state. At the same time, however, methanotrophs consume much of the methane produced. Therefore, methanogen abundance, when normalized by methanotroph abundance, can explain $\mathrm{CH}_{4}$ transfer velocity differences in a peat bog where diffusive transport from pore water in saturated layers is dominant. We conclude that microbial communities, and their control by variation in water table depth, are the key drivers of variability in $\mathrm{CH}_{4}$ fluxes across multiple hydro-biological zones in kettle-hole peat bogs. Future research should examine whether such patterns can be confirmed in other ecosystems where plant-mediated transport of $\mathrm{CH}_{4}$ is low.

Code and data availability. The data and the code used in this paper are available upon request. 


\section{Appendix A}

Table A1. Subset of amplicon-based lineages identified as genera of known methanogens and methanotrophs The genera found in the study are shown in bold letters.

\begin{tabular}{ll}
\hline Methanogens & Methanotrophs \\
\hline Methanobacterium & Methylocystis \\
Methanobrevibacter & Methylosinus \\
Methanocalculus & Methylocella \\
Methanocaldococcus? & Methylocapsa \\
Methanocella & Methyloferula \\
Methanococcoides & Methylococcus \\
Methanococcus & Methylocaldum \\
Methanocorpusculum & Methylomicrobium \\
Methanoculleus & Methylosphaera \\
Methanofollis & Methylomonas \\
Methanogenium & Methylobacter \\
Methanohalobium & Methylosarcina \\
Methanohalophilus & Methylothermus \\
Methanolacinia & Methylohalobius \\
Methanolinea & \\
Methanolobus & \\
Methanomassiliicoccus & \\
Methanomethylovorans & \\
Methanomicrobium & \\
Methanomicrococcus & \\
Methanoplanus & \\
Methanopyrus & \\
Methanoregula & \\
Methanosaeta & \\
Methanosalsum & \\
Methanosarcina & \\
Methanosphaera & \\
Methanosphaerula & \\
Methanospirillum & \\
Methanothermobacter & \\
Methanothermococcus & \\
Methanothermus & \\
Methanotorris & \\
Methermicoccus & \\
Methanoflorens & \\
Methanomassilliicoccus & \\
Methanospaerula & \\
Methanospirillum & \\
Methanothrix & \\
& \\
\hline
\end{tabular}


Table A2. Water chemistry of the pore water in the eight locations of the study. The means (SD) are averages of four measurements taken throughout the growing season of 2017. Asterisks indicate means that are significantly higher than at least one other mean.

\begin{tabular}{|c|c|c|c|c|c|c|c|c|}
\hline Variable & Mat-N & Mat-S & Tam-N & Tam-S & Shrubs & Lagg & Res-N & Res-S \\
\hline $\mathrm{NO}_{3}\left(\mathrm{mgL}^{-1}\right)$ & $0.06(0.03)$ & $0.03(0.01)$ & $0.08(0.04)$ & $0.03(0)$ & $0.08(0.09)$ & $0.04(0.01)$ & $0.07(0.08)$ & $0.05(0.03)$ \\
\hline $\mathrm{EC}\left(\mathrm{dS} \mathrm{m}{ }^{-1}\right)$ & $0.04(0)$ & $0.04(0)$ & $0.08(0)$ & $0.08(0.03)$ & $0.06(0)$ & $0.07(0.02)$ & $0.09(0.04)^{*}$ & $0.08(0.01)$ \\
\hline $\mathrm{Al}\left(\mathrm{mg} \mathrm{L}^{-1}\right)$ & $0.57(0.07)$ & $0.47(0.07)$ & $0.64(0.08)$ & $0.18(0.07)$ & $0.27(0.11)$ & $1.07(0.28)^{*}$ & $0.34(0.25)$ & $0.79(0.35)$ \\
\hline $\mathrm{Ca}\left(\mathrm{mgL}^{-1}\right)$ & $3.1(0.36)$ & $3.15(1.03)$ & $4.4(0.62)^{*}$ & $1.46(0.5)$ & $2.55(0.65)$ & $4.52(1.17)$ & $4.39(1.45)^{*}$ & $4.16(1.59) *$ \\
\hline $\mathrm{K}\left(\mathrm{mgL}^{-1}\right)$ & $1.56(0.27)$ & $2.05(0.51)$ & $2.38(0.45)$ & $2.42(0.28)$ & $2.38(0.25)$ & $9.41(10.83)$ & $2.06(0.62)$ & $9.29(12.63)$ \\
\hline $\operatorname{Mg}\left(\mathrm{mgL}^{-1}\right)$ & $0.91(0.09)$ & $0.85(0.1)$ & $1.38(0.11)$ & $0.53(0.11)$ & $0.91(0.08)$ & $1.24(0.27)$ & $1.09(0.44)$ & $0.89(0.27)$ \\
\hline $\operatorname{Mn}\left(\mathrm{mgL}^{-1}\right)$ & $0.05(0)$ & $0.05(0)$ & $0.11(0.01)^{*}$ & $0.04(0.01)$ & $0.07(0.01)$ & $0.09(0.03)^{*}$ & $0.1(0.01)^{*}$ & $0.1(0.03)^{*}$ \\
\hline $\mathrm{Na}\left(\mathrm{mgL}^{-1}\right)$ & $1.07(0.33)$ & $1.1(0.31)$ & $1.55(0.21)$ & $1.69(0.28)$ & $1.55(0.17)$ & $2(0.77)$ & $2.5(1.64)$ & $2.09(0.34)$ \\
\hline$P\left(\mathrm{mg} \mathrm{L}^{-1}\right)$ & $0.07(0.02)$ & $0.04(0.01)$ & $0.16(0.04)$ & $0.04(0.02)$ & $0.06(0.06)$ & $0.1(0.06)$ & $0.07(0.05)$ & $0.33(0.16)^{*}$ \\
\hline
\end{tabular}

* Level of significance $p<0.05$. 


\section{Appendix B}

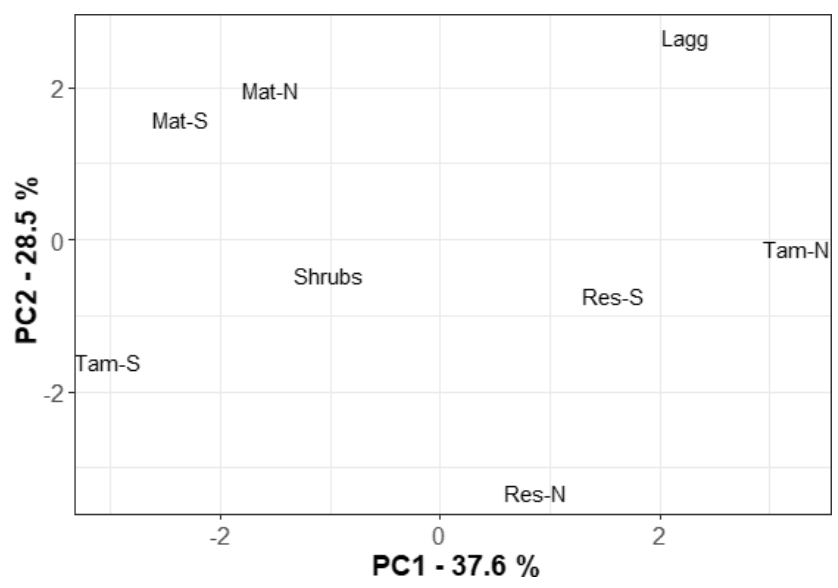

Figure B1. Principal component analysis of the 14 variables listed in Table A2.

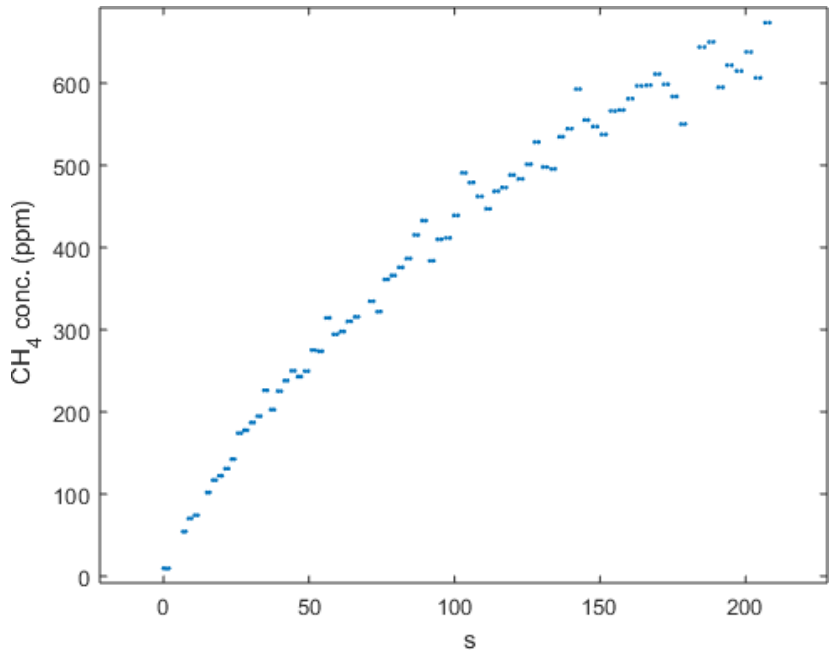

Figure B2. Chamber measurement during the September hotspot in the Tam-N location. Note the steady increase in concentration that indicates that ebullition was not the reason for the high magnitude of the flux at this location. 


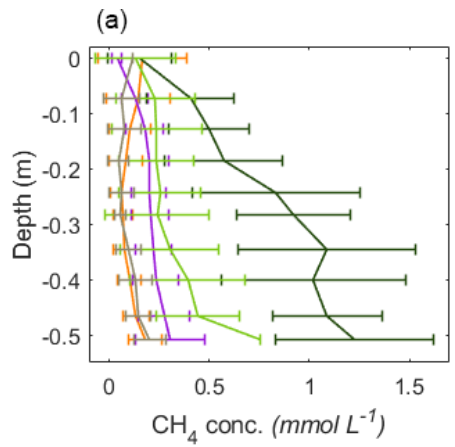

(b)

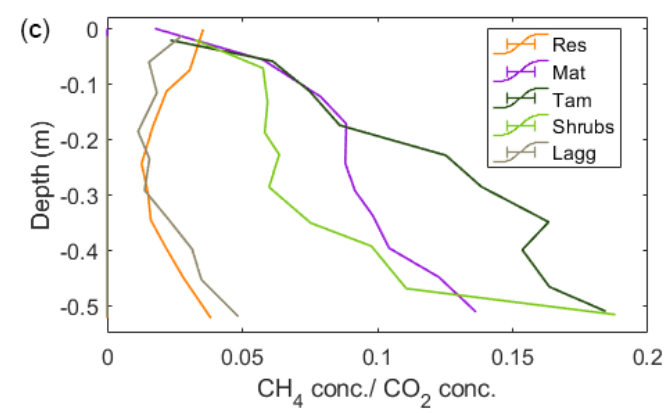

Figure B3. Vertical profiles of $\mathrm{CH}_{4}$ and $\mathrm{CO}_{2}$ pore-water concentrations $(\mathbf{a}, \mathbf{b})$ and the resulting $\mathrm{CH}_{4}: \mathrm{CO}_{2}$ ratios $(\mathbf{c})$. 
Author contributions. CRS, GB, and GMD designed the experiments. CRS, JS, RGA, and YH conducted field and laboratory observations. VIR and YFL generated the microbial analyses. CRS prepared the paper, with contributions from all co-authors.

Competing interests. The authors declare that they have no conflict of interest.

Acknowledgements. We thank Bryan Cassidy, Dominique Hadad, Anna Thompson, Julio Quevedo, Austin Rechner, and Alexa Baratucci for their assistance in the field in 2017 and Tasmina Uddin, Tim Becker, Charles Davis, Jorge Villa, Theresia Yasbeck, Taylor Stephen, Yang Ju, and Cassandra Rey for their assistance in the field in 2018. We thank Julian Deventer for insights on the analysis of the data. We also thank Karen Seidel and The Nature Conservancy for granting access to the site.

Financial support. This research has been supported by the Ohio State University Presidential Fellowship to Camilo Rey-Sanchez, the Ohio Water Resources Center (grant no. G16AP00076) and the Ohio Agricultural Research and Development Center, Ohio State University (grant no. SEEDS 2016-055).

Review statement. This paper was edited by Tina Treude and reviewed by two anonymous referees.

\section{References}

Angel, R., Matthies, D., and Conrad, R.: Activation of Methanogenesis in Arid Biological Soil Crusts Despite the Presence of Oxygen, PLOS ONE, 6, e20453, https://doi.org/10.1371/journal.pone.0020453, 2011.

Angle, J. C., Morin, T. H., Solden, L. M., Narrowe, A. B., Smith, G. J., Borton, M. A., Rey-Sanchez, C., Daly, R. A., Mirfenderesgi, G., Hoyt, D. W., Riley, W. J., Miller, C. S., Bohrer, G., and Wrighton, K. C.: Methanogenesis in oxygenated soils is a substantial fraction of wetland methane emissions, Nat. Commun., 8, 1567, https://doi.org/10.1038/s41467-017-01753-4, 2017.

Apprill, A., McNally, S., Parsons, R., and Weber, L.: Minor revision to V4 region SSU rRNA 806R gene primer greatly increases detection of SAR11 bacterioplankton, Aquat. Microb. Ecol., 75, 129-137, https://doi.org/10.3354/ame01753, 2015.

Basiliko, N., Blodau, C., Roehm, C., Bengtson, P., and Moore, T. R.: Regulation of decomposition and methane dynamics across natural, commercially mined, and restored northern peatlands, Ecosystems, 10, 1148-1165, https://doi.org/10.1007/s10021007-9083-2, 2007.

Basiliko, N., Henry, K., Gupta, V., Moore, T. R., Driscoll, B. T., and Dunfield, P. F.: Controls on bacterial and archaeal community structure and greenhouse gas production in natural, mined, and restored Canadian peatlands, Front. Microbiol., 4, 215, https://doi.org/10.3389/fmicb.2013.00215, 2013.
Bohn, T. J., Lettenmaier, D. P., Sathulur, K., Bowling, L. C., Podest, E., McDonald, K. C., and Friborg, T.: Methane emissions from western Siberian wetlands: heterogeneity and sensitivity to climate change, Environ. Res. Lett., 2, 4, https://doi.org/10.1088/1748-9326/2/4/045015, 2007.

Bridgham, S. D. and Richardson, C. J.: Mechanisms controlling soil respiration $\left(\mathrm{CO}_{2}\right.$ and $\left.\mathrm{CH}_{4}\right)$ in southern peatlands, Soil Biol. Biochem., 24, 1089-1099, https://doi.org/10.1016/00380717(92)90058-6, 1992.

Bridgham, S. D., Cadillo-Quiroz, H., Keller, J. K., and Zhuang, Q. L.: Methane emissions from wetlands: biogeochemical, microbial, and modeling perspectives from local to global scales, Glob. Change Biol., 19, 1325-1346, https://doi.org/10.1111/gcb.12131, 2013.

Cai, S. and Yu, Z.: Response of a warm temperate peatland to Holocene climate change in northeastern Pennsylvania, Quaternary Res., 75, 531-540, https://doi.org/10.1016/j.yqres.2011.01.003, 2011.

Caporaso, J. G., Kuczynski, J., Stombaugh, J., Bittinger, K., Bushman, F. D., Costello, E. K., Fierer, N., Peña, A. G., Goodrich, J. K., Gordon, J. I., Huttley, G. A., Kelley, S. T., Knights, D., Koenig, J. E., Ley, R. E., Lozupone, C. A., McDonald, D., Muegge, B. D., Pirrung, M., Reeder, J., Sevinsky, J. R., Turnbaugh, P. J., Walters, W. A., Widmann, J., Yatsunenko, T., Zaneveld, J., and Knight, R.: QIIME allows analysis of highthroughput community sequencing data, Nat. Methods, 7, 335336, https://doi.org/10.1038/nmeth.f.303, 2010.

Chamberlain, S. D., Anthony, T. L., Silver, W. L., Eichelmann, E., Hemes, K. S., Oikawa, P. Y., Sturtevant, C., Szutu, D. J., Verfaillie, J. G., and Baldocchi, D. D.: Soil properties and sediment accretion modulate methane fluxes from restored wetlands, Glob. Change Biol., 24, 4107-4121, https://doi.org/10.1111/gcb.14124, 2018.

Chasar, L. S., Chanton, J. P., Glaser, P. H., and Siegel, D. I.: Methane concentration and stable isotope distribution as evidence of rhizospheric processes: Comparison of a fen and bog in the Glacial Lake Agassiz Peatland complex, Ann. Bot., 86, 655-663, https://doi.org/10.1006/anbo.2000.1172, 2000.

Christen, A., Jassal, R. S., Black, T. A., Grant, N. J., Hawthorne, I., Johnson, M. S., Lee, S. C., and Merkens, M.: Summertime greenhouse gas fluxes from an urban bog undergoing restoration through rewetting, Mires Peat, 17, 1-24, https://doi.org/10.19189/MaP.2015.OMB.207, 2016.

Chu, H. S., Chen, J. Q., Gottgens, J. F., Ouyang, Z. T., John, R., Czajkowski, K., and Becker, R.: Net ecosystem methane and carbon dioxide exchanges in a Lake Erie coastal marsh and a nearby cropland, J. Geophys. Res.-Biogeo., 119, 722-740, https://doi.org/10.1002/2013jg002520, 2014.

Ciais, P., Gasser, T., Paris, J. D., Caldeira, K., Raupach, M. R., Canadell, J. G., Patwardhan, A., Friedlingstein, P., Piao, S. L., and Gitz, V.: Attributing the increase in atmospheric $\mathrm{CO}_{2}$ to emitters and absorbers, Nat. Clim. Change, 3, 926, 2013.

Colwell, S. R.: Characterization of Upland/Wetland Community Types: Changes to Flatiron Lake Bog over a 24-Year Period, The Ohio State University, available at: https://etd.ohiolink.edu/ pg_10?0::NO:10:P10_ETD_SUBID:68741 (last access: $23 \mathrm{Au}-$ gust 2019), 2009.

Crill, P. M., Bartlett, K. B., Harriss, R. C., Gorham, E., Verry, E. S., Sebacherl, D. I., Madsar, L., and Sanner, W.: Methane flux 
from minnesota peatlands, Glob. Biogeochem. Cy., 2, 371-384, https://doi.org/10.1029/GB002i004p00371, 1988.

Dean, J. F., Middelburg, J. J., Röckmann, T., Aerts, R., Blauw, L. G., Egger, M., Jetten, M. S. M., Jong, A. E. E. de, Meisel, O. H., Rasigraf, O., Slomp, C. P., in't Zandt, M. H., and Dolman, A. J.: Methane Feedbacks to the Global Climate System in a Warmer World, Rev. Geophys., 56, 207-250, https://doi.org/10.1002/2017RG000559, 2018.

Dedysh, S. N.: Cultivating Uncultured Bacteria from Northern Wetlands: Knowledge Gained and Remaining Gaps, Front. Microbiol., 2, 184, https://doi.org/10.3389/fmicb.2011.00184, 2011.

Dise, N. B.: Methane emission from minnesota peatlands - spatial and seasonal variability, Glob. Biogeochem. Cy., 7, 123-142, https://doi.org/10.1029/92gb02299, 1993.

Glatzel, S., Basiliko, N., and Moore, T.: Carbon dioxide and methane production potentials of peats from natural, harvested, and restored sites, eastern Quebec, Canada, Wetlands, 24, 261-267, https://doi.org/10.1672/02775212(2004)024[0261:cdampp]2.0.co;2, 2004.

Godin, A., McLaughlin, J. W., Webster, K. L., Packalen, M., and Basiliko, N.: Methane and methanogen community dynamics across a boreal peatland nutrient gradient, Soil Biol. Biochem., 48, 96-105, https://doi.org/10.1016/j.soilbio.2012.01.018, 2012.

Greenup, A. L., Bradford, M. A., McNamara, N. P., Ineson, P., and Lee, J. A.: The role of Eriophorum vaginatum in $\mathrm{CH} 4$ flux from an ombrotrophic peatland, Plant Soil, 227, 265-272, https://doi.org/10.1023/a:1026573727311, 2000.

Hatala, J. A., Detto, M., and Baldocchi, D. D.: Gross ecosystem photosynthesis causes a diurnal pattern in methane emission from rice, Geophys. Res. Lett., 39, L06409, https://doi.org/10.1029/2012gl051303, 2012.

Holgerson, M. A., Farr, E. R., and Raymond, P. A.: Gas transfer velocities in small forested ponds, J. Geophys. Res.-Biogeo., 122, 1011-1021, https://doi.org/10.1002/2016JG003734, 2017.

Hoyos-Santillan, J., Lomax, B. H., Large, D., Turner, B. L., Boom, A., Lopez, O. R., and Sjogersten, S.: Quality not quantity: Organic matter composition controls of $\mathrm{CO}_{2}$ and $\mathrm{CH}_{4}$ fluxes in neotropical peat profiles, Soil Biol. Biochem., 103, 86-96, https://doi.org/10.1016/j.soilbio.2016.08.017, 2016.

Kelly, C. A., Dise, N. B., and Martens, C. S.: Temporal variations in the stable carbon isotopic composmon of methane emitted from minnesota peatlands, Glob. Biogeochem. Cy., 6, 263-269, https://doi.org/10.1029/92gb01478, 1992.

Kettunen, A.: Connecting methane fluxes to vegetation cover and water table fluctuations at microsite level: A modeling study, Glob. Biogeochem. Cy., 17, 1051, https://doi.org/10.1029/2002gb001958, 2003.

Kim, J., Verma, S. B., and Billesbach, D. P.: Seasonal variation in methane emission from a temperate Phragmites-dominated marsh: effect of growth stage and plant-mediated transport, Glob. Change Biol., 5, 433-440, https://doi.org/10.1046/j.13652486.1999.00237.x, 1999.

Kim, S. Y., Lee, S. H., Freeman, C., Fenner, N., and Kang, H.: Comparative analysis of soil microbial communities and their responses to the short-term drought in bog, fen, and riparian wetlands, Soil Biol. Biochem., 40, 2874-2880, https://doi.org/10.1016/j.soilbio.2008.08.004, 2008.

Kirschke, S., Bousquet, P., Ciais, P., Saunois, M., Canadell, J. G., Dlugokencky, E. J., Bergamaschi, P., Bergmann, D., Blake, D.
R., Bruhwiler, L., Cameron-Smith, P., Castaldi, S., Chevallier, F., Feng, L., Fraser, A., Heimann, M., Hodson, E. L., Houweling, S., Josse, B., Fraser, P. J., Krummel, P. B., Lamarque, J. F., Langenfelds, R. L., Le Quere, C., Naik, V., O’Doherty, S., Palmer, P. I., Pison, I., Plummer, D., Poulter, B., Prinn, R. G., Rigby, M., Ringeval, B., Santini, M., Schmidt, M., Shindell, D. T., Simpson, I. J., Spahni, R., Steele, L. P., Strode, S. A., Sudo, K., Szopa, S., van der Werf, G. R., Voulgarakis, A., van Weele, M., Weiss, R. F., Williams, J. E., and Zeng, G.: Three decades of global methane sources and sinks, Nat. Geosci., 6, 813-823, https://doi.org/10.1038/ngeo1955, 2013.

Kostka, J. E., Weston, D. J., Glass, J. B., Lilleskov, E. A., Shaw, A. J., and Turetsky, M. R.: The Sphagnum microbiome: new insights from an ancient plant lineage, New Phytol., 211, 57-64, https://doi.org/10.1111/nph.13993, 2016.

Kotsyurbenko, O. R., Chin, K. J., Glagolev, M. V., Stubner, S., Simankova, M. V., Nozhevnikova, A. N., and Conrad, R.: Acetoclastic and hydrogenotrophic methane production and methanogenic populations in an acidic West-Siberian peat bog, Environ. Microbiol., 6, 1159-1173, https://doi.org/10.1111/j.1462-2920.2004.00634.x, 2004.

Kuznetsova, A., Brockhoff, P. B., and Christensen, R. H. B.: lmerTest Package: Tests in Linear Mixed Effects Models, J. Stat. Softw., 82, 1-26, https://doi.org/10.18637/jss.v082.i13, 2017.

Lai, D. Y. F.: Methane Dynamics in Northern Peatlands: A Review, Pedosphere, 19, 409-421, 2009.

Lai, D. Y. F., Moore, T. R., and Roulet, N. T.: Spatial and temporal variations of methane flux measured by autochambers in a temperate ombrotrophic peatland, J. Geophys. Res.-Biogeo., 119, 864-880, https://doi.org/10.1002/2013jg002410, 2014.

Lansdown, J. M., Quay, P. D., and King, S. L.: $\mathrm{CH}_{4}$ production via $\mathrm{CO}_{2}$ reduction in a temperate bog: A source of ${ }^{13} \mathrm{C}$ depleted $\mathrm{CH}_{4}$, Geochim. Cosmochim. Ac., 56, 3493-3503, https://doi.org/10.1016/0016-7037(92)90393-W, 1992.

Lee, H. J., Kim, S. Y., Kim, P. J., Madsen, E. L., and Jeon, C. O.: Methane emission and dynamics of methanotrophic and methanogenic communities in a flooded rice field ecosystem, FEMS Microbiol. Ecol., 88, 195-212, https://doi.org/10.1111/1574-6941.12282, 2014.

Le Mer, J. and Roger, P.: Production, oxidation, emission and consumption of methane by soils: A review, Eur. J. Soil Biol., 37, 25-50, https://doi.org/10.1016/s1164-5563(01)01067-6, 2001.

Lenth, R., Singmann, H., Love, J., Buerkner, P., and Herve, M.: emmeans: Estimated Marginal Means, aka Least-Squares Means, available at: https://CRAN.R-project.org/package=emmeans, last access: 24 December 2018.

Liu, Y. C. and Whitman, W. B.: Metabolic, phylogenetic, and ecological diversity of the methanogenic archaea, in: Incredible Anaerobes: From Physiology to Genomics to Fuels, vol. 1125, edited by: Wiegel, J., Maier, R. J., and Adams, M. W. W., pp. 171-189, 2008.

MacDonald, L. H., Paull, J. S., and Jaffe, P. R.: Enhanced semipermanent dialysis samplers for long-term environmental monitoring in saturated sediments, Environ. Monit. Assess., 185, 36133624, https://doi.org/10.1007/s10661-012-2813-8, 2013.

Malhotra, A., Roulet, N. T., Wilson, P., Giroux-Bougard, X., and Harris, L. I.: Ecohydrological feedbacks in peatlands: an empirical test of the relationship among vegetation, mi- 
crotopography and water table, Ecohydrology, 9, 1346-1357, https://doi.org/10.1002/eco.1731, 2016.

McCalley, C. K., Woodcroft, B. J., Hodgkins, S. B., Wehr, R. A., Kim, E.-H., Mondav, R., Crill, P. M., Chanton, J. P., Rich, V. I., Tyson, G. W., and Saleska, S. R.: Methane dynamics regulated by microbial community response to permafrost thaw, Nature, 514, 478-481, https://doi.org/10.1038/nature13798, 2014.

Moore, P. D.: The future of cool temperate bogs, Environ. Conserv., 29, 3-20, https://doi.org/10.1017/s0376892902000024, 2002.

Moore, T. R. and Dalva, M.: The influence of temperature and water-table position on carbon-dioxide and methane emissions from laboratory columns of peatland soils, J. Soil Sci., 44, 651664, 1993.

Morin, T. H., Bohrer, G., Naor-Azrieli, L., Mesi, S., Kenny, W. T., Mitsch, W. J., and Schaefer, K. V. R.: The seasonal and diurnal dynamics of methane flux at a created urban wetland, Ecol. Eng., 72, 74-83, https://doi.org/10.1016/j.ecoleng.2014.02.002, 2014.

Morin, T. H., Bohrer, G., Stefanik, K. C., Rey-Sanchez, A. C., Matheny, A. M., and Mitsch, W. J.: Combining eddycovariance and chamber measurements to determine the methane budget from a small, heterogeneous urban floodplain wetland park, Agric. Forest Meteorol., 237, 160-170, https://doi.org/10.1016/j.agrformet.2017.01.022, 2017.

Nadeau, D. F., Rousseau, A. N., Coursolle, C., Margolis, H. A., and Parlange, M. B.: Summer methane fluxes from a boreal bog in northern Quebec, Canada, using eddy covariance measurements, Atmos. Environ., 81, 464-474, https://doi.org/10.1016/j.atmosenv.2013.09.044, 2013.

Nahlik, A. M. and Mitsch, W. J.: Methane Emissions From Created Riverine Wetlands, Wetlands, 30, 783-793, https://doi.org/10.1007/s13157-010-0038-6, 2010.

Nelson, M. C., Morrison, H. G., Benjamino, J., Grim, S. L., and Graf, J.: Analysis, Optimization and Verification of IlluminaGenerated 16S rRNA Gene Amplicon Surveys, PLOS ONE, 9, e94249, https://doi.org/10.1371/journal.pone.0094249, 2014.

Oleszczuk, R. and Truba, M.: The analysis of some physical properties of drained peat-moorsh soil layers, Ann. Wars. Univ. Life Sci. 00 SGGW Land Reclam., 45, 41-48, https://doi.org/10.2478/sggw-2013-0004, 2013.

Pangala, S. R., Moore, S., Hornibrook, E. R. C., and Gauci, V.: Trees are major conduits for methane egress from tropical forested wetlands, New Phytol., 197, 524-531, https://doi.org/10.1111/nph.12031, 2013.

Parada, A. E., Needham, D. M., and Fuhrman, J. A.: Every base matters: assessing small subunit rRNA primers for marine microbiomes with mock communities, time series and global field samples, Environ. Microbiol., 18, 1403-1414, https://doi.org/10.1111/1462-2920.13023, 2016.

Pugh, C. A., Reed, D. E., Desai, A. R., and Sulman, B. N.: Wetland flux controls: how does interacting water table levels and temperature influence carbon dioxide and methane fluxes in northern Wisconsin?, Biogeochemistry, 137, 15-25, https://doi.org/10.1007/s10533-017-0414-x, 2018.

Raghoebarsing, A. A., Smolders, A. J. P., Schmid, M. C., Rijpstra, W. I. C., Wolters-Arts, M., Derksen, J., Jetten, M. S. M., Schouten, S., Damste, J. S. S., Lamers, L. P. M., Roelofs, J. G. M., den Camp, H., and Strous, M.: Methanotrophic symbionts provide carbon for photosynthesis in peat bogs, Nature, 436, 1153-1156, https://doi.org/10.1038/nature03802, 2005.
R Development Core Team: R: A language and environment for statistical computing., available at: http://www.R-project.org (last access: 7 January 2019), 2018.

Rey-Sanchez, A. C., Morin, T. H., Stefanik, K. C., Wrighton, K., and Bohrer, G.: Determining total emissions and environmental drivers of methane flux in a Lake Erie estuarine marsh, Ecol. Eng., 114, 7-15, https://doi.org/10.1016/j.ecoleng.2017.06.042, 2018.

Schilder, J., Bastviken, D., Hardenbroek, M., and van and Heiri, O.: Spatiotemporal patterns in methane flux and gas transfer velocity at low wind speeds: Implications for upscaling studies on small lakes, J. Geophys. Res.-Biogeo., 121, 1456-1467, https://doi.org/10.1002/2016JG003346, 2016.

Schneider, C. A., Rasband, W. S., and Eliceiri, K. W.: NIH Image to ImageJ: 25 years of image analysis, Nat. Methods, 9, 671-675, https://doi.org/10.1038/nmeth.2089, 2012.

Segers, R.: Methane production and methane consumption: a review of processes underlying wetland methane fluxes, Biogeochemistry, 41, 23-51, https://doi.org/10.1023/a:1005929032764, 1998.

Sha, C., Mitsch, W. J., Mander, U., Lu, J. J., Batson, J., Zhang, L., and He, W. S.: Methane emissions from freshwater riverine wetlands, Ecol. Eng., 37, 16-24, https://doi.org/10.1016/j.ecoleng.2010.07.022, 2011.

Shannon, R. D. and White, J. R.: 3-year study of controls on methane emissions from 2 Michigan peatlands, Biogeochemistry, 27, 35-60, 1994.

Smemo, K. A. and Yavitt, J. B.: Anaerobic oxidation of methane: an underappreciated aspect of methane cycling in peatland ecosystems?, Biogeosciences, 8, 779-793, https://doi.org/10.5194/bg8-779-2011, 2011.

Strack, M. and Zuback, Y. C. A.: Annual carbon balance of a peatland $10 \mathrm{yr}$ following restoration, Biogeosciences, 10, 2885-2896, https://doi.org/10.5194/bg-10-2885-2013, 2013.

Sundqvist, E., Crill, P., Molder, M., Vestin, P., and Lindroth, A.: Atmospheric methane removal by boreal plants, Geophys. Res. Lett., 39, L21806, https://doi.org/10.1029/2012gl053592, 2012.

Treat, C. C., Bubier, J. L., Varner, R. K., and Crill, P. M.: Timescale dependence of environmental and plant-mediated controls on $\mathrm{CH}_{4}$ flux in a temperate fen, J. Geophys. Res.-Biogeo., 112, G01014, https://doi.org/10.1029/2006jg000210, 2007.

Turetsky, M. R., Kotowska, A., Bubier, J., Dise, N. B., Crill, P., Hornibrook, E. R. C., Minkkinen, K., Moore, T. R., Myers-Smith, I. H., Nykanen, H., Olefeldt, D., Rinne, J., Saarnio, S., Shurpali, N., Tuittila, E. S., Waddington, J. M., White, J. R., Wickland, K. P., and Wilmking, M.: A synthesis of methane emissions from 71 northern, temperate, and subtropical wetlands, Glob. Change Biol., 20, 2183-2197, https://doi.org/10.1111/gcb.12580, 2014.

Updegraff, K., Pastor, J., Bridgham, S. D., and Johnston, C. A.: Environmental and substrate controls over carbon and nitrogen mineralization in northern wetlands, Ecol. Appl., 5, 151-163, https://doi.org/10.2307/1942060, 1995.

US EPA, O.: EPA Method 350.1: Determination of Ammonia Nitrogen by Semi-Automated Colorimetry, US EPA, available at: https://www.epa.gov/homeland-security-research/epa-method3501-determination-ammonia-nitrogen-semi-automatedcolorimetry (last access: 5 March 2019), 2015a. 
US EPA, O.: SW-846 Test Method 6010D: Inductively Coupled Plasma-Optical Emission Spectrometry (ICP-OES), US EPA, available at: https://www.epa.gov/hw-sw846/sw-846-testmethod-6010d-inductively-coupled-plasma-optical-emissionspectrometry-icp-oes (last access: 5 March 2019), 2015 b.

Van der Nat, F., Middelburg, J. J., Van Meteren, D., and Wielemakers, A.: Diel methane emission patterns from Scirpus lacustris and Phragmites australis, Biogeochemistry, 41, 1-22, https://doi.org/10.1023/a:1005933100905, 1998.

Vitt, D. H. and Slack, N. G.: An analysis of the vegetation of Sphagnum-dominated kettle-hole bogs in relation to environmental gradients, Can. J. Bot., 53, 332-359, https://doi.org/10.1139/b75-042, 1975.

Waddington, J. M. and Day, S. M.: Methane emissions from a peatland following restoration, J. Geophys. Res.-Biogeo., 112, 112, https://doi.org/10.1029/2007jg000400, 2007.

Walters, W., Hyde, E. R., Berg-Lyons, D., Ackermann, G., Humphrey, G., Parada, A., Gilbert, J. A., Jansson, J. K., Caporaso, J. G., Fuhrman, J. A., Apprill, A., and Knight, R.: Improved Bacterial 16S rRNA Gene (V4 and V4-5) and Fungal Internal Transcribed Spacer Marker Gene Primers for Microbial Community Surveys, mSystems, 1, e00009-15, https://doi.org/10.1128/mSystems.00009-15, 2016.
Wang, Z. P., Delaune, R. D., Masscheleyn, P. H., and Patrick, W. H.: Soil redox and ph effects on methane production in a flooded rice soil, Soil Sci. Soc. Am. J., 57, 382-385, 1993.

Wanninkhof, R.: Relationship between wind speed and gas exchange over the ocean revisited, Limnol. Oceanogr.-Methods, 12, 351-362, https://doi.org/10.4319/lom.2014.12.351, 2014.

White, J. R., Shannon, R. D., Weltzin, J. F., Pastor, J., and Bridgham, S. D.: Effects of soil warming and drying on methane cycling in a northern peatland mesocosm study, J. Geophys. Res.Biogeo., 113, G00A06, https://doi.org/10.1029/2007jg000609, 2008.

Whiting, G. J. and Chanton, J. P.: Plant-dependent $\mathrm{CH}_{4}$ emission in a subarctic canadian fen, Glob. Biogeochem. Cy., 6, 225-231, https://doi.org/10.1029/926b00710, 1992. 